\title{
THE UNIVERSITY'S ROLE IN PROMOTING MTNORITY GROUP EMPLOYMENT IN THE CONSTRUCTION INDUSTRY
}

\author{
Antonia H. Chayes $†$ \\ CHRISTOPHER L. KaUFMAN $\dagger \dagger$ \\ RAYMoNd L. WHEeLER, JR. $\dagger^{\dagger} \dagger$
}

Guaranteeing equal employment opportunity in federally created jobs has traditionally been at the forefront of the Government's attack on nationwide racial discrimination. This emphasis reflects the Government's ostensibly great ability to change patterns of employment where the sanction of withholding federal funds is available.

A series of executive orders has been promulgated to effectuate these policies. ${ }^{1}$ Currently effective is Executive Order 11246, ${ }^{2}$ requiring that contractors on projects involving federal funds shall "not discriminate against any employee or applicant for employment because of race, color, religion, sex, or national origin." 3 Moreover, the contractor is obligated to "take affirmative action to ensure that applicants are employed, and that employees are treated during employment, without regard to their race, color, religion, sex or national origin." 4

Responsibility for the administration of this Order resides in the Secretary of Labor. The Secretary has broad rulemaking power to define the scope of the contractor's duty of affirmative action. ${ }^{5}$ In addition, both the Secretary and the contracting agency have authority to initiate investigations and to hold hearings to determine compliance. $^{\mathfrak{c}}$ Finally, these same parties are delegated authority to invoke severe sanctions against noncomplying contractors, ranging from can-

$\dagger$ Associate Professor of Political Science, Tufts University. A.B. 1949, Radcliffe College; J.D. 1953, George Washington University. Member, District of Columbia Bar. Mrs. Chayes is the former Dean of Jackson College, Tufts University.

it B.A. 1967, Amherst College; J.D. 1970, Harvard University.

iti B.A. 1967, University of Texas; J.D. 1970, Harvard University.

I See Note, Executive Order 11246: Antidiscrimination Obligations in Government Contracts, 44 N.Y.U.L. REv. 590, 590 (1969).

23 C.F.R. 402 (1970), 42 U.S.C. $\$ 2000 \mathrm{e}$ (Supp. V, 1970).

3 Exec. Order No. 11,246 \$202, 3 C.F.R. 402 (1970), 42 U.S.C. $\$ 2000$ e (Supp. $\mathrm{V}, 1970)$ (emphasis added).

4 Id. (emphasis added).

5 Id. $\$ 201,3$ C.F.R. 402 (1970), 42 U.S.C. $\$ 2000$ e (Supp. V, 1970).

${ }^{6}$ Id. $\$ \S 206,208,3$ C.F.R. 405 (1970), 42 U.S.C. $\$ 2000$ e (Supp. V, 1970). 
celling the contract and blacklisting the contractor from federally funded contracts to recommending judicial action by the Attorney General. $^{7}$

An additional party becomes involved in the case of federally assisted construction contracts. Executive Order 11246 imposes a duty on the grantee of federal funds to "assist and cooperate actively with the administering department or agency and the Secretary of Labor in obtaining the compliance of contractors and subcontractors with those contract provisions and with the rules, regulations, and relevant orders of the Secretary." 8 Although the Order appears to contemplate grantee action solely at the behest of the Government, some grantees may come under independent pressure to foster minority employment. A university engaged in a program of continued construction, for example, may be pressured by its students to compensate for what the students consider the Government's failure to effectuate a policy of equal employment. Further, the pervasiveness of the problem of minority group employment argues for the university's assertion of leadership in easing the problem at least in its own construction projects.

For such an institution, Executive Order 11246 may provide a legal mechanism for furthering minority group employment. This Article explores the problems, both practical and legal, facing universities attempting such action. After a preliminary discussion of the conditions underlying racial imbalance in the construction industry, the Article introduces as a case study the dispute over employment practices in the construction of a Tufts University dormitory. The study highlights the impact of a crisis situation in which legal factors can form only a part of the basis for decisions. Both the judicial and administrative remedies open to a university under an operative contract are then discussed in a more general context. The Article next considers the university's options before it has completed negotiating its construction contract. Finally, a broader perspective is assumed and proposals for both concerted university action and a refocusing of governmental energies are evaluated.

\section{Racial Imbalance in the Construction Industry}

The construction industry has been increasingly attacked by both the public and private sectors for racially discriminatory employment practices. At first glance, emphasis on construction might seem curious in view of the overall magnitude of the equal employment opportunity

TId. \$\$ 209-12, 3 C.F.R. $406-07$ (1970), 42 U.S.C. \$2000e (Supp. V, 1970).

8 Id. $\$ 301,3$ C.F.R. 408 (1970), 42 U.S.C. $\$ 2000$ e (Supp. V, 1970). 
problem. ${ }^{9}$ Statistics reveal that racial imbalance in the building trades is neither greater nor less than in most other occupations. A recent Equal Employment Opportunity Commission survey of the racial composition of building trades local unions operating referral systems, although perhaps not accurate in absolute terms, ${ }^{10}$ does reflect recognizable trends. Black membership in the unions is not proportionate to the racial composition of the total population. The study found 8.4 percent black membership overall in the reported trades. Membership in representative trades was found to be as follows:

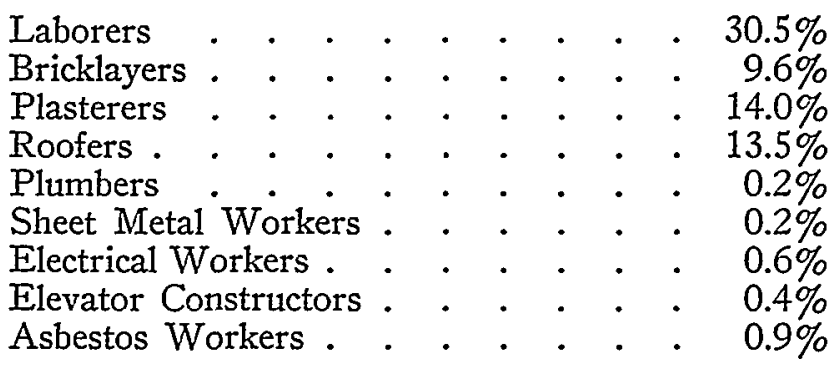

These statistics are not surprising: they reveal a pattern prevalent throughout American industry. ${ }^{11}$ In the construction industry minority groups fill a relatively high proportion of low skill, low wage trades (laboring, bricklaying, roofing) but a virtually insignificant proportion of the skilled crafts (electrical work, plumbing, sheet metal work).

Yet the construction industry comes under especially heavy fireprobably in part because of its connection with institutional building. Large institutional building projects are eminently visible, and racial imbalance among the workmen is readily identifiable. ${ }^{\mathbf{2}}$ Moreover, because much institutional construction is publicly financed, political means for exerting pressure for nondiscriminatory hiring are available. ${ }^{13}$ Finally, although construction pays relatively high wages, its blue-collar identification causes many to believe that it is more accessible to those with inferior educational and training qualifications than white-collar occupations. ${ }^{14}$

9 See D. Bok \& J. Dunlop, Labor and the American Community 128-29 (1970) ; D. Q. Mills, The Construction Industry: Adjustments for Minority Group Entry 13, Jan. 27, 1970 (unpublished paper) [hereinafter cited as Mills].

${ }_{10}$ EEOC Reveals Statistics on Minority Menbership in Unions, EEOC News Release (Sept. 28, 1969). The data was based on returns from only 3700 of 5000 locals operating hiring halls, and covered less than $1 / 3$ of the industry's work force. Mills 7.

11 Mills 11; see Bok \& Dunlop, supra note 9, at 124-29.

12 Interview with James E. Flynn, Attorney for Vappi Constr. Co. of Cambridge, Mass., in Cambridge, Mass., Mar. 13, 1970 [hereinafter cited as Flynn Interview].

${ }_{13}$ Cf. Strauss \& Ingerman, Public Policy and Discrimination in Apprenticeship,

16 Hastings L.J. 285, 314-15 (1965).

14 Mills 15-16; Flynn Interview. 
Thus racial discrimination in the construction industry attracts attention because it is easily perceived and unexpected, and because the means of amelioration are thought to be readily at hand. Universities, as recipients of substantial amounts of federal construction funds, may face pressures to insure equitable minority employment because they are expected to be both intolerant of discrimination and in a position to act against it. Assessment of the prospects for effective university action demands a realistic appraisal of both the structure of the construction industry and the causes of racial imbalance within it.

\section{A. Characteristics of the Construction Industry}

\section{Decentralization}

On a single university construction project several contractors usually perform disparate tasks. A large general contractor normally carries out with his own manpower the basic structural phases of the work, such as carpentry, cement finishing, and bricklaying; but a group of specialty trade subcontractors actually perform the bulk of the work. ${ }^{15}$ These subcontractors, ordinarily responsible for installing plumbing, plastering, heating, and electrical wiring, provide their own labor and materials and are subject only to the supervision of the general contractor for the proper performance of their specialized jobs. This decentralization of functions has two principal causes. First, institutional and commercial building construction is a complex process involving numerous operations, each requiring a high degree of specialized knowledge and skill. ${ }^{16}$ Second, entrenched craft tradition among workers has fostered a powerful guild system consisting of numerous craft unions representing particular specialized trades. ${ }^{17} \mathrm{Be}-$ cause employment control lies largely with these unions, decentralized decisionmaking has been perpetuated in the industry and has carried over to employers. As a result, on any particular project, sixty to ninety percent of the total dollar volume of the work goes to subcontractors performing approximately seventeen to twenty-five different trade functions. ${ }^{18}$

\section{Mobility}

Work demands on any particular project often fluctuate so much that a particular craft or contractor may be involved at the site only

$15 \mathrm{~W}$. Haber \& H. Levinson, Labor Relations and Productivity in the BuILDING TRADES 19 (1956) [hereinafter cited as HABER \& Levinson]; Flynn Interview.

16 Haber \& Levinson 19.

17 See id. 31.

18 Flynn Interview. 
for brief and intermittent periods and then with varying manpower needs. Crews constantly shift on and off the job as work progresses, and at no time are all the men and crews eventually employed present simultaneously. Accordingly, the labor force moves from employer to employer, and any single contractor may have a turnover of from 150 to 200 percent during the course of a single project. $^{19}$ In general, a contractor's volume of operations is too small to permit the steady employment of a full-time complement of qualified journeymen; rather, in addition to his permanent staff of "key men," he needs a readily available labor supply of skilled workers from which he may draw. This need and the strong craft structure in the industry enable the union locals to become the centralized regional pools for recruitment and referral.

\section{The Unnions}

Several peculiar ramifications flow from the functioning of union locals as regional manpower pools.

\section{a. Collective Bargaining}

Collective bargaining in the building trades reflects the regional approach to employment and accentuates the role of unions as de facto employers. The often unpredictable demands for the rapid redistribution of men in the regional labor pool among various projects require a preestablished and uniform understanding of employment terms for all jobs and all contractors ${ }^{20}$ transcending any particular project.

Although difficult to generalize, ${ }^{21}$ collective bargaining is typically carried out between specialty craft union locals and contractor associations. ${ }^{22}$ For example, in Boston the general contractors bargain through the Associated General Contractors of Massachusetts and the Building Trades Employers' Association; these groups negotiate agreements with the craft union locals ordinarily employed by the general contractors. ${ }^{23}$ Many subcontractors have formed similar associations-such as the Master Plasterers of Boston-to negotiate with individual specialty craft unions. ${ }^{24}$ The unions in turn are loosely bound together in the Building and Construction Trades Department

$19 I d$.

20 See Sherman, Legal Status of the Building and Construction Trades Unions in the Hiring Process, 47 GEo. L.J. 203, 205 (1958).

21 See HABER \& LeVINSON 40-42.

$22 I d .40$.

23 E.g., Agreement of Associated Gen. Contractors of Mass., Inc., and Building Trades Emp'rs' Ass'n of Boston \& E. Mass., Inc., with Cement Masons Local 534, Apr. 30, 1969.

24 See Haber \& Levinson 38; Flynn Interview. 
within the AFL-CIO. ${ }^{25}$ Local building trades councils, like the Building and Construction Trades Council in Boston, attempt coordination and control of the other organizations. ${ }^{26}$ In some cities these councils bargain with contractor associations over certain general provisions and "declarations of principles"; but with few exceptions individual craft representatives negotiate wage rates and working rules. ${ }^{27}$

\section{b. Union Hiring Halls}

This fractionalized nature of bargaining has given craft union locals considerable power. ${ }^{28}$ In addition to being the central referral agencies for their areas, the locals either have obtained the additional security of preferential hiring hall provisions with the union largely determining job qualifications or, despite nonexclusive agreements, have operated such halls in practice. ${ }^{29}$ For example, in a typical agreement the contractor notifies the hiring hall first whenever a vacancy arises, and the union refers any available workers qualified according to a predetermined priority scheme. ${ }^{30}$ Only if the hall has no men to refer will the contractor turn elsewhere for workers. Prior to the passage of the Taft-Hartley Act in 1947, similar hiring hall agreements were written into collective bargaining agreements partially to perpetuate the "closed shop" (referral of union members exclusively). Taft-Hartley outlawed the "closed shop" and substituted the less exclusive "union shop." 31 In the construction industry, ${ }^{32}$ under a

25 HABER \& LEVINSON 31.

26 Id. 33.

27 Id. 40-41.

28 Id. 30-31.

29 Flynn Interview.

30 E.g., Agreement, supra note 23.

31 Labor-Management Relations Act \$ 8(a) (3), 29 U.S.C. \$158(a) (3) (1964); see Note, Unilateral Union Control of Hiring Halls: The Wrong and the Renedy, 70 YALE L.J. 661, 663 (1961).

32 In 1959, Congress amended the Taft-Hartley Act by adding, inter alia, $\S 8(f)$, 29 U.S.C. $\$ 158(\mathrm{f})$ (1964), to clarify the applicability of the Act to the construction industry. It provides that:

(f) It shall not be an unfair labor practice under subsections (a) and (b) of this section for an employer engaged primarily in the building and construction industry to make an agreement covering employees engaged (or who, upon their employment, will be engaged) in the building and construction industry with a labor organization of which building and construction employees are members (not established, maintained, or assisted by any action defined in subsection (a) of this section as an unfair labor practice) because (1) the majority status of such labor organization has not been established under the provisions of section 159 of this title prior to the making of such agreement, or (2) such agreement requires as a condition of employment, membership in such labor organization after the seventh day following the beginning of such employment or the effective date of the agreement, whichever is later, or (3) such agreement requires the employer to notify such labor organization of opportunities for employment with such employer, or gives such labor organization an opportunity to refer qualified applicants for such employment, or (4) such agreement specifies minimum training or ex- 
"union shop" agreement, nonunion members may be hired and allowed to work for seven or thirty days before being required to join the union, and any union member cannot be expelled from a union operating a union shop for any offense other than nonpayment of dues. The courts have upheld exclusive union hiring hall arrangements, but only if the hall operates to assure equal referral to both union members and nonunion workers. ${ }^{33}$

Despite legal prohibition, many sectors of the construction industry retain arrangements resembling the "closed shop." 34 "Contractors have delegated much responsibility for judging job qualifications to the unions. Unions in turn attempt to standardize the skill and content of their craft as a means of job and wage control by setting membership and referral standards $;^{35}$ union membership then becomes identified with skill and is often crucial both in referral and hiring. ${ }^{36}$

\section{Entrance Into the Construction Trades}

\section{a. The Skilled Trades}

In the more skilled mechanical trades, the unions largely control entry through private negotiations or by promoting the passage of legislation enhancing their control. A good example arose in the area of apprenticeship training, one of the major means of entry into the skilled trades. ${ }^{37}$ The National Apprenticeship Act of $1937^{38}$ authorized the establishment of the Bureau of Apprenticeship and Training (BAT) in the Department of Labor, primarily to promote apprenticeship programs run by joint labor-management committees. ${ }^{39}$ An apprenticeship program meeting certain minimum standards may be registered ${ }^{40}$ with BAT or with a cooperating state agency with stand-

perience qualifications for employment or provides for priority in opportunities for employment based upon length of service with such employer, in the industry or in the particular geographical area: Provided, That nothing in this subsection shall set aside the final proviso to subsection $8(a)(3)$ of this section: Provided ficther, That any agreement which would be invalid, but for clause (1) of this subsection, shall not be a bar to a petition filed pursuant to section 159 (c) or 159 (e) of this title.

33 See, e.g., NLRB v. Local 269, Elec. Workers, 357 F.2d 51 (3d Cir. 1966) ; NLRB v. Operating Engineers Local 382-382A, 279 F.2d 951 (8th Cir. 1960); cf. Carpenters Local 60 v. NLRB, 365 U.S. 651 (1961).

34 HABER \& LEVINSON 71.

35 See F. R. Marshali \& V. Briggs, The Negro and Apprenticeship 13 (1967) [hereinafter cited as MARSHAII \& BRIGGS].

${ }^{36}$ See Haber \& Levinson 71; Sherman, supra note 20, at 205-06.

37 Mills 49-50. (1964).

38 Act of Aug. 16, 1937, ch. 663, 50 Stat. 664, as amended 29 U.S.C. $\$ \$ 50-50 \mathrm{~b}$

39 Marshali \& Briggs 11-13.

40 Once registered, an apprenticeship program is also subject to the nondiscrimination provisions promulgated by the Secretary of Labor. See 29 C.F.R. $\$ \S 30.1-30.16$ (1970). See generally M. Sovern, Legal Restraints on Raclal Discrimination in EMTLOYMENT 194-97 (1966). 
ards comparable to BAT's. ${ }^{41}$ Unions and employers may determine their own apprenticeship requirements, and if they administer their own programs in compliance with the broad regulations set by BAT or state agencies, BAT gives them technical assistance. ${ }^{22}$ The ultimate sanction for noncompliance with the regulations is deregistration of the apprenticeship program. ${ }^{43}$ Although this remedy may not seem very meaningful, it does assume importance with regard to apprenticeship programs involved in the construction of federally funded university buildings. The Davis-Bacon Act" governs the wages of "mechanics and laborers" on federal public works contracts involving more than $\$ 2,000$. Regulations provide that "[a]pprentices will be permitted to work as such only when they are registered" with BAT or a cooperating state agency. ${ }^{45}$ Any employee listed on the payroll at an apprentice wage rate but not registered "shall be paid the wage rate determined by the Secretary of Labor for the classification of work he actually performed," which often means the journeyman scale. ${ }^{46}$ To preserve the incentive provided by graduated pay scales and to avoid undue expense to contractors, most apprenticeship programs are registered. ${ }^{47}$

The unions retain a great deal of control over the standards for entry and the numbers of applicants to be accepted. ${ }^{48}$ Largely to foster job and wage control and to control the supply of labor, the unions have set high prerequisites for apprenticeship programs: for example, applicants may be required to have a high school diploma, to meet specified age requirements, to exhibit good moral character, and to be free of a criminal record. ${ }^{49}$ Restrictive journeymanapprentice ratios, ${ }^{50}$ state licensing laws, ${ }^{51}$ and often unnecessarily long apprentice programs ${ }^{52}$ further deter prospective applicants. Only a

41 See 29 C.F.R. $\$ 30.16$ (1970) ; SovERN, supra note 40, at 195-96.

42 Marshall \& Briggs 11.

4329 C.F.R. \$30.11(b) (1970). Apprenticeship programs administered by contractors subject to Executive Order 11246 are subject to the nondiscrimination regulations whether or not they are registered. See 41 C.F.R. $\$ \$ 60-1.1$ to 60-1.47 (1970). Thus noncompliance could lead to those sanctions available against substantive violations of the Executive Order.

4440 U.S.C. $\$ \$ 276 a$ to $276 a-7$ (1964) (originally enacted as ch. 411, 46 Stat. $1494(1931))$.

4529 C.F.R. $\$ 5.5(\mathrm{a})(4)(1970)$.

46 Id.; see Mills 51 .

47 See Mills 49.

48 Marshali \& Briggs 13.

49 Id. 13, 15-17.

50 To keep employers from abusing the use of apprenticeship labor and to limit the number of apprentices, each trade sets a fixed ratio of apprentices to journeymen. See E. Hain, Black Labor in the Boston Construction Industry 5, 1969 (unpublished thesis in Harvard Law School Library). Moreover, various state statutes have limited apprentice/journeymen ratios in several trades. E.g., MASS. GEN. LAwS ANN. ch. 142, § 3A (1965) (1 plumbers' apprentice per journeyman).

51 Flynn Interview.

52 See Marshatl \& Briggs 22. 
few openings in these programs are available each year in the most desirable trades. ${ }^{53}$ Other means of entry into the skilled trades are at least as limited. Although apprenticeship currently accounts for a declining percentage of workers in many trades, ${ }^{54}$ hiring "off the street" by union referral or, if a hiring hall is nonexclusive, by a contractor directly, is uncommon. Only workers with relatively high qualifications, gained through experience in related trades or in training programs, can pass the union-administered journeyman's examination. ${ }^{55}$

\section{b. The Less Skilled Trades}

In manual labor and carpentry, in the "trowel trades" of masonry, bricklaying, and cement finishing, and in other trades requiring relatively little skill, entry is easier through nonapprenticeship routes. ${ }^{56}$ Depending on the hiring hall arrangement, a worker with some experience or training can gain access either through union referral or direct contractor employment. In some of these less skilled trades there are journeyman retraining and upgrading programs and both private and public training programs. ${ }^{57}$

5. The Limits of University Influence on Industry Policies

Decentralization and the predominance of the union locals in the construction industry make it difficult for the university to reach effectively all the parties necessary to achieve racial balance. Dealing directly with only a general contractor, the university has no formal bargaining relationship with either the subcontractors or the union locals. Moreover, an analysis of the causes of racial imbalance in the construction industry indicates that the structure of the industry further isolates the university.

\section{B. The Causes of Racial Imbalance in the Construction Industry}

\section{Overt Racial Discrimination}

The most obvious barriers to minority group employment in the building trades are present overt discrimination and the continuing effects of past discrimination.

53 Id. 18-19; Hain, supra note 50, at 7.

54 Strauss, Apprenticeship: An Evaluation of the Need, in EMployment PoLICY AND THE LABOR MARKET 302-05 (A. Ross ed. 1965).

55 There is some evidence that unions augment their labor supply both by having members work substantial overtime and by granting temporary work permits. The latter practice suggests that institutionalized qualification requirements are overly restrictive. Cf. Note, Title VII of the Civil Rights Act of 1964 and Minority Group Entry into the Building Trades, 37 U. CHI. L. REv, 328, 349-50 (1970).

56 Milis 49-50.

57 Id. 48. 


\section{a. Contractors}

The precise extent of overt discrimination practiced by construction contractors is unknown, but presumably they hold the same attitudes regarding racial minorities that are widespread in society. ${ }^{58}$ Contractor discrimination should not, however, be overemphasized. High levels of construction activity in the recent past have led many contractors to recognize minority group workers as a potential source of new manpower." As one commentator has stated, "[I]n many areas there are no more insistent and (in some cases) effective advocates of increased minority participation in the building trades than the employers." 60

\section{b. Unions}

Certain building trades unions have overtly pursued racially discriminatory membership, referral, and training policies. ${ }^{61}$ And even when these unions have ceased overt discrimination, nepotistic rules perpetuate its past effects. ${ }^{62}$ The national union leadership has urged an end to racial prejudice, but the attitudes of the local membership, in whom the real union power lies, continue to reflect discriminatory attitudes prevalent in the society at large. ${ }^{63}$ Such attitudes, when fortified by widespread fear of job competition perhaps deriving from the pervasive job insecurity in the construction industry, and by feelings that nepotism is both moral and proper, become particularly hard to change. $^{64}$

\section{Educational and Cultural Factors}

Even when fair employment laws have eliminated overt racial discrimination and its vestigial influence on business decisions, racial imbalance remains. ${ }^{65}$ Statistics demonstrating that racial imbalance in the construction industry is confined primarily to the more skilled trades reinforce the view that general societal discrimination in education and housing is largely responsible. Insufficient numbers of minority group workers are qualified or desire to become qualified in construction skills. Recruitment and training are the crucial problems. For ex-

58 Marshall, \& BRIGGS 34.

59 Mills 20.

${ }^{60} \mathrm{Id}$.

${ }^{61}$ See, e.g., Dobbins v. Local 212, Electrical Workers, 292 F. Supp. 413, 443 (S.D. Ohio 1968). 1969).

62 See, e.g., Local 53, Asbestos Workers v. Vogler, 407 F.2d 1047, 1054 (5th Cir.

63 See BoK \& Dunlop, supra note 9, at 134-35.

64 See Marsharl \& Briggs 36.

65 Mills, supra note 9, at 17-19; see BoK \& DuNLor, supra note 9, at 130-31; Hain, supra note 50 , at 11 . 
ample, educational, test score, and noncriminal record requirements screen out large numbers of interested minority group applicants. ${ }^{68}$ The residential concentration of minority groups in central cities exacerbates transportation expenses associated with an industry often requiring workers to travel into the suburbs. ${ }^{67}$ Cultural factors further decrease the number of minority group members desiring to work in the building trades. In many of the trades, there is a strong base of fixed ethnic composition; a skilled trade is often passed from father to son. ${ }^{68}$ The minority group communities lack a tradition in craft work because of past discrimination and the recent arrival of many blacks who abandoned agricultural employment in the South. ${ }^{69}$ Often the workers have some skills applicable to several trades but none developed sufficiently to meet the specifications of any particular craft. $^{\text {70 }}$

\section{Conclusion}

If a university could negotiate directly with all of the parties in the construction industry complex, it still could not completely remedy minority underemployment on its construction projects by obtaining promises of nondiscrimination. The causes of racial imbalance are too pervasive for solution by simple and direct university action. The large pool of qualified minority group workers needed to achieve a proper balance simply does not exist, and those workers who are qualified often prefer to stay in the minority group communities to work on local projects rather than travel to the suburbs where many universities are located. The solution to racial imbalance requires extensive changes in recruitment, improvements in training, and alteration of overly restrictive job qualifications, areas traditionally controlled by the unions or joint union-contractor committees. The university is thus far removed from both the parties and the means essential to increasing minority employment in the construction industry.

\section{Case Study: The Construction of a Dormitory at Jackson College for Women, Tufts University}

The controversy began in October 1969, when the Tufts AfroAmerican Society, composed of black undergraduates, delivered to the

66 Marshall \& Briggs 41-45.

67 See BoK \& Dunlop, sipra note 9, at 130.

68 Flynn Interview, supra note 12; see Marshali \& Briggs 18; cf. Haber \& LEVINSON, supra note 15 , at 73 . at 292 .

60 See Marserall \& Briggs 37-41. See also Strauss \& Ingerman, supra note 13,

70 Telephone interview with Paul Parks, Dir. of the Model Cities Administration of Boston, in Boston, Mass., Apr. 10, 1970. 
university eight demands relating to the hiring of minority group workers on a dormitory project. The cost of the dormitory was $1,914,500$ dollars, of which the federal government was to lend ninety percent. $^{71}$ The focal demand of the students was that at least twenty percent of the work force on the job be black and third-world workers. ${ }^{72}$

\section{A. The Parties}

The parties to the controversy do not fit the normal model for a legal action. They were not the parties to a typical law suit, nor, in fact, were they all parties to the law suit filed in the case. They were not the parties contemplated by administrative arrangements, ${ }^{73}$ and they were certainly not the parties in a usual labor-management controversy. In fact, the failure of each to anticipate the presence and recognize the interests of at least some of the others aggravated all of their problems.

\section{The University}

A relatively small, private university, Tufts enrolls 4415 students in its three undergraduate colleges, its graduate school of arts and sciences, and the Fletcher School of Law and Diplomacy, and employs 310 full faculty. The university's main campus is located at Medford, Massachusetts, about ten miles northwest of Boston. With limited

71 Contract between Trustees of Tufts College and John A. Volpe Constr. Co., Aug. 7,1968 , on file at office of Trustees of Tutts College.

72 By "third world workers," the students said they meant to include not only Asians but also Puerto Ricans and other Spanish-speaking people who are represented both in Boston and among construction workers. The students also demanded that:

2. The [college] Administration take whatever actions that are necessary to insure that contractors and sub-contractors immediately hire and continually employ the proposed number of Black and Third World Peoples.

3. The administration, contractor, and sub-contractors contact the New Urban League to secure Blacks skilled in the building trades.

4. The administration cooperate with the co-chairman of the Labor Committee of Afro in monitoring the hiring and treatment of Black and Third World workers on the Jackson dormitory.

5. The co-chairman of the Labor Committee be invited to observe negotiations sessions with contractors and sub-contractors on the new dormitory.

6. The administration submit weekly written reports to Afro on the situation of Black and Third World workers.

7. On the construction of the new dormitory and on future construction and renovation projects, the administration and its contractors should aggressively seek Black sub-contractors.

8. The administration begin discussions on the construction of the new medical center with the Labor Committee and representatives of the Black community.

Letter from Dan Coleman and Charles Yancey, co-chairmen of the Labor Comm. of the Tufts Univ. Afro-Am. Soc'y, to Burton C. Hallowell, Pres., Tufts Univ.; C. Russell de Burlo, V. Pres., Tufts Univ.; Albert D. Ullman, Provost, Tufts Univ.; and Antonia H. Chayes, Dean, Jackson Coll.; undated (delivered Oct. 20, 1969). T3 See 41 C.F.R. $\$ 60-1.21$ (1970). 
endowment and alumni support, the university relies heavily on tuition fees.

\section{The Contractor}

The Volpe Construction Company, which held the dormitory contract, is a major nationwide construction firm with contracts worth forty-four million dollars in seven states. The Volpe company is a member of the Associated General Contractors, on whom it relied during all negotiations. Its labor force consists largely of the workers from less skilled trades : laborers, bricklayers, and carpenters. It relies on subcontractors for more skilled and specialized work. There were nineteen subcontractors on the Jackson dormitory job.

\section{Students}

Tufts undergraduate colleges contained 137 black students who organized the Afro-American Society in the spring of 1969. The university had initiated a large-scale recruitment effort to enroll black students in 1968, and by 1969 had achieved 7.7 percent representation in the freshman class. Even though other students strongly supported the Afro-American Society, black and white students maintained separate leadership throughout the Jackson dispute.

\section{The Unions}

The construction was under a union shop contract. Fifteen unions were represented but, at the time the controversy began, only eleven were on the job. ${ }^{74}$ Some of them, Local 22 of the Laborer's Union for example, had heavy black representation. Others had scarcely any. All were represented by Fred M. Ramsey of the Building and Construction Trades Council. In October 1969, all the black workers on the job were union members.

\section{The Federal Government}

The Department of Housing and Urban Development was the grantor agency. It operated under Executive Order 11246 and was responsible for the development and implementation of a satisfactory affirmative action program in each contract it approved. ${ }^{75}$ It operates

74 Lists from the Office of Facilities, Planning, \& Constr., Tufts Univ., July 1970. The following locals represented the unions: Carpenters Local 218, Laborers Local 22, Cement Masons Local 534, Bricklayers Local 3, Electrical Workers Local 103, Pipefitters Local 537, Plumbers Local 12, Engineers Local 12, Ironworkers Local 7, Lathers \& Roofers Local 33, Sheet Metal Workers Local 17.

75 See Exec. Order No. 11,246 \$303(a), 3 C.F.R. 408 (1970), 42 U.S.C. \$2000e (Supp. V, 1970). 
in the first instance at the regional level, through the regional officer of equal employment opportunity. In matters of contract compliance, however, it is ultimately responsible to the Office of Federal Contract Compliance (OFCC) in the Department of Labor $^{76}$ which also maintains regional offices. This dual responsibility caused substantial confusion in administrative procedure.

\section{B. The Facts}

\section{The Demands}

The student demand for a twenty percent quota implied a concrete and numerical approach to the obligation of affirmative action. It represented a complete departure from Volpe's essentially procedural affirmative action program ${ }^{77}$ accepted by both HUD and the university and incorporated into the construction contract. The contract provided for appointment of an equal employment opportunity officer, dissemination throughout the company of information on equal employment opportunity policy, and "particular efforts" at recruitment of minority group workers. Potential sources of black employees were listed: "schools, colleges, employment offices, union offices and other recruitment sources." The phrase "an Equal Opportunity Employer" was to be placed in all advertisements. The contract promised training, placement, and promotion efforts described as "vigorous."

All of these provisions are boilerplate terms, merely recapitulating the language of Executive Order 11246. This careful verbal compliance with the Order has become the standard approach throughout the industry ${ }^{78}$ but has not been challenged by the Government. Neither Tufts nor the HUD Area Engineer objected to this affirmative action plan at the preconstruction conference ${ }^{79}$ with Volpe on August 28, 1968.

A Notice to Proceed had been issued on August 9, 1968. Nevertheless, deficiencies in the contractual program were recognized. Most serious were (1) the absence of affirmative action plans from the two subcontractors with contracts of 100,000 dollars or more as required

76 See id. $\$ 205,3$ C.F.R. 404-05 (1970), 42 U.S.C. $\S 2000 \mathrm{e}$ (Supp. V, 1970); 41 C.F.R. $\$ 60-1.6$ (1970).

77 John A. Volpe Constr. Co., Affirmative Action Plan for Jackson College Residence Hall, Tufts Univ., submitted Aug. 1968, copy on file at Office of Facilities, Planning, \& Constr., Tufts Üniv.

78 See, e.g., Joint Apprentice \& Training Comm. for the Elec. Contracting Indus. of Greater Boston, Affirmative Action Program (approved by the Comm. of Mass., Compliance Title 29, Jan. 10, 1966) ; Building Trades Employers Ass'n of Boston \& E. Mass., BTEA Newsletter, Bull. No. 9 (June 18, 1968).

79 See generally 41 C.F.R. $\$ 60-1.40$ (a) (1970) (requirements of affirmative action compliance programs), quoted at text accompanying note 104 infra. 
by HUD regulations, ${ }^{80}$ and (2) the failure of Volpe to hire an equal employment opportunity officer as its own affirmative action program required. Notwithstanding these problems, ground was broken on the project on September 28, 1968.

On April 8, 1969, the two delinquent subcontractors still had not submitted affirmative action programs. The HUD Area Engineer consequently set a deadline of April 17 for the completion of the total program. The two subcontractors filed their plans in time, but the Area Engineer found the plumbing subcontractor's plan to be "worthless," ${ }^{81}$ although he gave neither reasons for this appraisal nor guidelines for revision. He accepted a rewritten affirmative action plan on April 30, 1969. Thus, despite the requirement that a satisfactory affirmative action program be developed for the entire project within 120 days after commencement of the contract, ${ }^{82}$ Volpe failed to complete its program until seven months after construction began. Even then, the program was adequate only on paper. HUD officials recognized the program's weaknesses, but took no corrective action.

The university repeatedly inquired throughout the spring and summer of 1969 about Volpe's efforts to recruit minority group workers. In response, Volpe sent the university summaries of its telephone job orders to nonunion black recruitment sources. These summaries uniformly recorded either failure to make contact with the source or, if contact was made, failure of the source to produce the desired workers. ${ }^{83}$ But, even though university pressure for more vigorous recruitment and more regular reporting increased during the summer, Tufts never took the position that Volpe had failed to comply with Executive Order 11246 until the black students began to express their concern in the autumn.

Student requests for more minority group workers coincided with increases in the work force. The black students discussed their requests with Provost Ullman in late September before making demands. University officials anticipated strong student action and summoned

80 U.S. Dep't of Housing \& Urban Devel., Form No. 907, Instructions for Contractors Regarding Affirmative Action Under Executive Order 11246, July, 1967. An OFCC regulation requires subcontractors with 50 or more employees and a contract worth $\$ 50,000$ or more to develop a written affirmative action compliance program. 41 C.F.R. $\$ 60-1.40$ (a) (1970).

81 Letter from George E. Meyer, HUD Area Engineer, to Lawrence L. Ketchen, Dir. of Facilities, Planning, \& Constr., Tufts Univ., Apr. 18, 1969, on file at Office of Facilities, Planning, \& Constr., Tufts Univ.

82 See 41 C.F.R. $\$ 60-1.40$ (c) (1970).

83 Memorandum from David Mirabassi, V. Pres., Volpe Constr. Co., to Ralph Niles, Equal Emp't Opportunity Officer, Volpe Constr. Co., Apr. 17, 1969, copy on file at Office of $V$. Pres., Tufts Univ. The memorandum lists 13 telephone calls to Martin Gopen, Director of Labor and Transportation of the Urban League in Boston. It includes such notations as: "Mr. Gopen not in"; or, after an order for two carpenters had been placed, "The men did not show up." 
colleagues responsible for academic and student affairs to cope with the problem, until then solely the concern of physical plant personnel. Simultaneously, the university began to negotiate with Volpe for a sharp increase in the numbers of minority group workers. On October 1 , there were only six black or Puerto Rican workers in a total construction crew of 107.

A first meeting with company president Peter Volpe and his recently appointed equal employment opportunity officer was inconclusive. The contractor explained his efforts to recruit black workers, and his problems with absenteeism and turnover among them. $\mathrm{He}$ cited the inadequate transportation between Boston, where the black workers lived, and the Medford construction site. Volpe's work force then consisted primarily of laborers, carpenters, and bricklayers, trades with a relatively high proportion of blacks. Volpe pointed out, however, that workers from the mechanical trades would soon be required on the job and that there were virtually no blacks in those unions. The university officials called for a meeting with the mechanical trade subcontractors, which was set for October 22.

Meanwhile, the university sought outside held in defining an effective affirmative action program, and in ascertaining what results in terms of minority group employment could reasonably be expected. Among those consulted were Robert Randolph, the HEW field engineer handling HUD's compliance problems in Boston, Reginald Brown and Howard Shelton, compliance officers for the Boston Redevelopment Authority, and Paul Parks, Boston's Model Cities Administrator. These men formed an informal advisory team concerned not only with the dormitory issue, but also with the twenty-seven million dollar Tufts New England Medical Center complex soon to be constructed in Boston's South End. They saw in 'Tufts' willingness to act in the Medford controversy a potential for imposing effective contract standards in the larger project, which might then be used as a model throughout the area.

On October 20, students invited Martin Gopen, Director of Labor and Transportation of the Urban League, and Leo Fletcher, leader of the United Community Construction Workers (UCCW), ${ }^{84}$ to an open meeting at which black students set a two-week deadline for compliance with their demands. Gopen justified the twenty percent minimum for minority group employment as fairly reflecting the racial composition of the Boston metropolitan area. ${ }^{85}$

84 UCCW is an independent, industrially organized union whose members are mostly, but not entirely, black construction workers.

${ }^{85}$ A 1968 study of Boston proper showed the city to be $17 \%$ black. UNITED Community Services of Metropolitan Boston, Research Dep't, Black and White IN Boston, Table 1, at 7 (1968). Another study found 16.9\%. HARVARD-MIT JorNT 
The total number of skilled minority workers presently unemployed or otherwise available for job openings was questioned. The university had been informed that few black journeymen were unemployed, particularly in the more skilled trades. Gopen denied any shortage and asserted there were 800 black construction workers in the area. Arguing that there would be no effective federal enforcement action, he called upon the university to suspend the contract and to accept the risk of liability for breach in order to force decisive action from Volpe, the Government, or both. This proposal became the focus of student and faculty demands as the controversy developed.

The October 22 meeting between Tufts, Volpe's officers, and the subcontractors recapitulated much of the earlier discussion. Several subcontractors stated they had sought blacks in their area ${ }^{86}$ for apprenticeship openings and had found none. And Gopen, they said, had failed to produce skilled workers on their request. The subcontractors did not answer directly the question whether, under their collective bargaining agreements, they could recruit outside the union locals' hiring halls. They called attention to the nondiscrimination clauses in their agreements, but spoke also of possible retaliation available to the union locals for outside hiring. The only concrete outcome of the meeting was Volpe's promise to place job orders for workers with UCCW and the Workers' Defense League, and to report these calls to Tufts, which could then monitor recruitment efforts on a current basis. The subcontractors made no such promises, although their work forces would be employed in the immediate future.

\section{Courses of Action Available to the University}

Eleven days before the student-imposed deadline the university consulted legal counsel. The university needed to select a course of action from one or more of the following alternatives.

\section{a. Court Action}

The university and its counsel considered the possibility of suing Volpe for failure to comply with its contractual affirmative action obligation. The lawsuit presented difficult jurisdictional and substantive questions. Even if these were surmounted, remedies were hard to predict: money damages appeared inappropriate, specific relief

Center for Urban Studies, Boston Area Study (1970) (to be published). Puerto Ricans are estimated to comprise $2.1 \%$ of the city's population. Id. Other races comprise less than 1\%. 1 U.S. BuReau of The Census, U.S. Census of Populaimon: 1960, Ceraracteristics of Population, pt. 23, Massachusetts (1960). The best estimates for the metropolitan area as a whole, however, give a black population of only 5\%. BLACK AND WHITE IN BOSTON, stpra, Table 1 , at 7.

86 These subcontractors are based in suburban Boston where few black people live. 
raised serious problems of enforcement, and a declaratory judgment might be ineffective. ${ }^{87}$ Moreover, there was the problem of delay and the possibility that completion of the construction would moot the issues before the case could be decided.

\section{b. Contract Cancellation}

Many students and faculty members wanted the university to suspend the contract and stop work on the job. This would have thrust the burden of initiating litigation or other remedial proceedings upon the contractor. The university would raise its claims that the affirmative action clauses had been breached by counterclaim. The university was prepared to accept the considerable delay in the completion of the contract this course would entail. The risk of substantial liability for damages caused Volpe by the delay was the most serious deterrent.

\section{c. Federal Agency Enforcement}

The university's informal advisory group of Boston and federal officials earlier suggested that recourse to administrative procedures might resolve the university's problems. Nevertheless, the procedure outlined by OFCC regulations appeared to be cumbersome, timeconsuming, and unavailable for a party with the university's standing. The thin record of administrative enforcement was also discouraging.

\section{d. Negotiation and Political Action}

Continued negotiation with Volpe seemed to be the most viable approach even though it appeared unlikely that Volpe would adopt either the numerical or percentage employment goals demanded by the students. Rather, Volpe was under extreme pressure to oppose the students' demands. The unions upon whom Volpe depends nationwide were firmly committed to fight any type of quota system. ${ }^{88}$ To shift the balance in the negotiations, the university would need to bring local and state governmental bodies, federal officials, and newspapers into the controversy. Concerted action by local universities appeared helpful not only as a means of intensifying public pressure on Volpe in this controversy, but also as the best possible source for long-range solutions.

\section{The University's Efforts}

In the following days the university tried to influence Volpe through all four possible courses of action outlined above.

87 Text accompanying notes $174-214$ infra.

${ }^{88}$ See Building \& Constr. Trades Council of the Metropolitan Dist. of Boston, News Release, Nov. 13, 1969. 
On the evening of October 31, university officials reviewed the situation with legal counsel. The consensus was that the university's case did not warrant suspending the job on the ground of noncompliance with the contract. The university's principle problem was that the federal officials responsible for securing compliance had accepted the contractor's affirmative action program as written, without determining whether the program was adequate. The lawyers recommended an action for declaratory and injunctive relief in the state court, where they thought it would be easier to defeat a motion to dismiss. Suit was accordingly filed in Middlesex Superior Court on November 3. Although the university was not wholly optimistic, it issued a press release expressing "hope of a precedent-setting decision." s9

At the same meeting the university decided to ask federal officials to review the situation fully preliminary to a request to initiate formal administrative compliance proceedings. The university realized that this weakened its lawsuit by strengthening the contractor's potential defense that the federal agencies had primary jurisdiction in determining compliance. Although an investigator from the HUD regional office compliance staff visited the university on November 3 and was given full access to files and records, neither he nor the unofficial advisory group expected speedy or definitive federal action. A second conference, held a week later, included HUD representatives from Washington and established a four-month timetable for administrative action, from initial investigation to ultimate decision. The university's standing to bring action was not questioned. At the time of the meeting, the Jackson dormitory was thirty-seven percent completed. It was expected to reach fifty-two percent of completion by the end of December, and seventy-five percent by March.

The university continued to negotiate with the contractor, and the contractor with the unions. On November 6, Volpe reported that five additional black workers had been hired, bringing the total then working on the project to twelve out of ninety-nine. Volpe refused to fix a numerical goal for minority group hiring, but concentrated on improving recruitment and reporting procedures. Volpe expressed willingness to negotiate with universities in the vicinity for the establishment of a training and apprenticeship program for minority group workers. But this latter possibility was dampened by Fred M. Ramsey, Secretary-Treasurer of the Building and Construction Trades Council, in reaction to a student attempt to close the construction site. On November 9, through a letter written by its counsel to Volpe, Tufts formally identified eleven specific job openings and demanded that

89 Tufts Univ., Office of Public Information, News Release, An Explanation to the University Community, Nov. 5, 1969. 
minority group workers be hired to fill them. Included were openings for two watchmen-jobs not provided for in the original contract, but for which the university was prepared to increase its contractual payments. Filling these positions would have brought minority group employment to twenty out of ninety-seven. Two weeks later Peter Volpe wrote to Tufts President Burton C. Hallowell, refusing to implement preferential hiring because of his company's contracts with the unions, "some of which require that the first inquiry for job vacancies be made with the subject union." 80

Meanwhile, President Hallowell urged other university presidents to cooperate in creating an interuniversity committee on equal employment opportunity which could develop a concerted strategy for dealing with affirmative action in federally assisted construction. It was estimated that, even excluding the new Boston campus of the University of Massachusetts, the universities would construct buildings in the Boston area worth 100 million dollars during the next three years. $^{91}$ By November 19, Boston University, MIT, and Brandeis expressed support for the suggested committee. Harvard declined to participate, however, despite pressure from its black students, preferring to seek solutions for its own problems independently. Wellesley College and Northeastern University later joined the group, and Harvard, in fact, participated informally.

On November 23 the interuniversity committee met with John Wilks, Director of the Office of Federal Contract Compliance. Wilks asked whether the universities would welcome a "Philadelphia Plan" for Boston, in which the Department of Labor would set areawide percentage goals for minority group hiring in specified construction trades. He indicated that the Department of Labor would devise a plan for Boston if it found enough support from many groups, including the black community. Six university presidents later sent a joint letter to the Secretary of Labor requesting such action from his department. ${ }^{22}$

The interuniversity committee also discussed the possibility of establishing an interuniversity contract compliance board. The committee considered several model clauses for contractual compliance, including a scheme requiring quotas. Draftsmen were charged with submitting proposed language for such clauses by December.

90 Letter from S. Peter Volpe, Pres., Volpe Constr. Co., to Burton C. Hallowell, Pres., Tufts Univ., Nov. 25, 1969, on file at Office of the Pres., Tufts Univ.

91 These estimates were developed informally by the interuniversity committee in December 1969. Interview with Quinn Mills, Indus. Rel. Prof., MIT, Apr. 9, 1970. 92 Letter from Morris B. Abram, Pres., Brandeis Univ.; Ruth Adams, Pres., Wellesley Coll.; Arland S. Christ-Janer, Pres., Boston Univ.; Burton C. Hallowell, Pres., Tufts Univ.; Howard W. Johnson, Pres., MIT; and Asa S. Knowles, Pres., Northeastern Univ.; to George P. Shultz, Sec'y of Labor, Dec. 22, 1969, copy on file at Office of Pres., Tufts Univ. 
Two more governmental agencies meanwhile entered the dispute: the Massachusetts Advisory Committee of the United States Civil Rights Commission and the Massachusetts Commission Against Discrimination.

The Massachusetts Advisory Committee, chaired by Father Robert F. Drinan, then dean of Boston College Law School, held a public hearing at Tufts on November 7, during the height of the student demonstrations. The committee members made an unannounced trip to the construction site, accompanied by university officers and black students. On the site black workers were questioned about the conditions of their employment and about union discrimination, black unemployment, and patterns of discrimination in the construction industry. All the black workers questioned were union men, and they surprised some students by stating that they were well treated on the job. Questioning of foremen and shop stewards revealed job openings, thus providing the university with guidance for its subsequent demand on Volpe for thirteen additional minority group employees. Father Drinan's committee made several recommendations, the most important being a four-day moratorium on police presence and student disruption. Although not formally adopted, the substance of this proposal was tacitly accepted by both the university and the students.

The onsite inspection and Tufts' subsequent demands on Volpe led to the hiring of two Haitian bricklayers on November 10. A week later they were fired, and a sharp dispute immediately arose over whether the contractor's action was discriminatory or justified by the men's unsatisfactory performance. The Massachusetts Commission Against Discrimination intervened on complaint from the fired bricklayers. After an informal hearing on November 24, the commission chairman requested that the contractor rehire the bricklayers for three weeks for a thorough evaluation of their work. Although this order was without legal sanction, Volpe complied. On November 25, when the two Haitian workers returned, the white masons did not report for work, stating that it was "too cold." They stayed out until December 2. On December 5 the architect found the black masons' work inadequate, the Massachusetts Commission Against Discrimination concurred, and the men were fired, this time without further ado.

\section{The Construction Site Confrontation}

All these negotiations occurred against a background of intensifying confrontation between students and administration at Tufts. From the time the black students set their November 3 deadline for action, the possibility of student disruption and the means for dealing with it 
became the prime considerations for the Tufts administration. The university had to determine what circumstances might compel it to call outside police to the campus, and whether it was contractually bound to provide protection for the construction site. And it had to consider whether the contractor could or would act if the university did not, and the likely form of police intervention at Volpe's behest.

The university had reported to black students on the progress of its negotiations, but had little success in allaying their demands. Two days after the deadline, at 6:30 a.m., November 5, students took over the construction site and barred the entrance. Leo Fletcher, head of the UCCW, appeared with seven black workers and claimed that he could produce five more by afternoon. The white workers arrived about 7:30 a.m., milled around, but did not attempt to enter the site. Volpe declared a "no work" day and hired two black bricklayers later in the day from among the workers Fletcher had produced but declared that there were no openings for the rest (carpenters and laborers). By noon the regular workers had dispersed, although it was unclear whether the subcontractors would pay their workmen for the day. The students then left the site. Fred M. Ramsey demanded that the university provide protection for his men, maintaining that they had a right to work and would not leave the site peacefully a second day. After other unsuccessful efforts to avert further disruption, the university filed a previously prepared application for an injunction in the Middlesex Superior Court. By late afternoon, the court issued a temporary restraining order narrowly delimiting permissible student action. $^{93}$ At 6:00 a.m., November 6, police from the Boston area surrounded the construction site. The Afro-American Society and its white student allies quickly withdrew.

An emergency faculty meeting, convened late in the day of the student takeover, voted after extensive debate to recommend that the president close the site. The vote was forty-eight to thirty-six with nine abstaining. This was the first significant consideration of the issues by the whole arts and sciences faculty. Four days later, however, the faculty reversed itself by an equally narrow vote on the basis of a report from an ad hoc committee appointed by the faculty committee on committees immediately after the first meeting.

On November 7, while Father Drinan was conducting his hearing, black and white students peacefully demonstrated at Ballou Hall, the university's administrative center. The demonstration was repeated on November 10 , and produced minor property damage.

93 Trustees of Tufts College v. Cox, Civil No. 30424 (Middlesex Super. Ct., Nov. 6. 1969). 
On November 12, 150 students picketed Volpe's office in Malden, Massachusetts, and then returned to Tufts and seized East Hall, the building containing the computer used by the university for data processing, payroll computation, and general administrative purposes. Minor property damage and one student injury during the course of the occupation heightened campus tensions. The occupation was ended at the end of the day after the Afro-American Society and President Hallowell signed a memorandum of understanding containing many terms proposed by the university. ${ }^{94}$ The memorandum provided that two additional minority group workers would be hired the next day, raising the total to thirteen out of ninety-nine. The two blacks to be hired immediately would fill night watchmen positions which Volpe had earlier agreed to provide. The university agreed "to continue to insist" that enough minority group workers be hired within seven days to comprise twenty percent of the work force and that the percentage be maintained. It agreed to hire a "clerk of the works . . . to monitor the quality and substance of the work," relying on the Afro-American Society "to produce candidates and giving those candidates first preference for the position." The Afro-American Society would select a student monitor to assist the clerk. The students at first insisted that the student monitor be consulted prior to the discharge of any minority group worker. The university's impotence in dealing with its contractor convinced negotiators that it could only agree to "consult" the student monitor when it learned of any firing. The memorandum of understanding, bearing phrases like the "University will begin negotiations" or "will insist," recognized the university's lack of power to make the changes demanded by students, however violent their demonstrations.

\section{The Outcome}

On November 13 the Building and Construction Trades Council issued a news release stating that: "[U]nion hiring procedures shall be strictly enforced. [The Council] will not be a party to any quota system, on any job, in any area. Court action will be sought against any employer who attempts to implement such a system." 95 Although the proportion of minority group workers rose to thirteen out of a declining force of ninety by November 18, only one minority group worker was employed by any of the subcontractors, whose work force would increase as Volpe's decreased. The work force declined to

94 Memorandum of Understanding Between Burton C. Hallowell, Pres., Tufts Univ., and George Cox, Charles Yancey, \& Dan Coleman, representatives, Tufts Univ, Afro-American Soc'y, Nov. 12, 1969, copy on file at Office of Pres., Tufts Univ. 95 Building \& Constr. Trades Council of the Metropolitan Dist. of Boston, News Release, Nov, 13, 1969. 
sixty-three by December 8 , with eight workers from minority groups. The number of minority group workers declined at a faster rate than the work force. On January 5 there were only five minority group workers left out of a total work force of fifty-two, and only one was employed by a subcontractor.

On December 5 the Middlesex Superior Court issued an interlocutory decree on Volpe's demurrer and subsequently dismissed the university's suit for declaratory relief without opinion and without leave to amend. ${ }^{96}$ The Supreme Judicial Court of Massachusetts ultimately reviewed this dismissal and ordered that the case be heard on its merits. ${ }^{97}$ But that court's action took place more than a year after the lower court's ruling, and months after the completion of the dormitory.

The Massachusetts Commission Against Discrimination held a formal hearing to investigate the complaint of the Haitian bricklayers on December 10 , but made no findings and issued no order for the rehiring of the workers.

Secretary Shultz answered the university presidents' letter on January 15, 1970:

Although we have done some preliminary interviewing for the purpose of formulating a compliance program for the Boston area, we are still hopeful that the industry and the minority community will solve the problem themselves.

If a home town solution is not forthcoming, however, it is our intention to resolve the problem with a Federal program. You may be assured that before such a program is finalized, a public hearing will be conducted to solicit relevant information from all segments of the community-including the academic communities. $^{98}$

By April 1970, the HUD investigation of Volpe had not yet produced results. The facts would not allow a finding of compliance, HUD had not achieved it by conciliation, and no notice for a hearing had yet issued.

\section{Disruption at Harvard}

By mid-November the Tufts crisis subsided and the agitation moved to Harvard. The dispute began over the wages and seniority status of black helpers on the painting crew in Harvard's Buildings and

96 Trustees of Tufts College v. Volpe Constr. Co., Civil No. 30415 (Middlesex Super. Ct., Dec. 19, 1969), rev'd, M-7379 (Mass. Sup. Jud. Ct., Dec. 8, 1970).

97 Trustees of Tufts College v. Volpe Constr. Co., M-7379 (Mass. Sup. Jud. Ct., Dec. 8, 1970).

98 Letter from George P. Shultz, Sec'y of Labor, to Burton C. Hallowell, Pres., Tufts Univ., Jan. 15, 1970, on file at Office of the Pres. Tufts Univ. Eventually a "hometown solution" was privately negotiated. This "Boston plan" is discussed at text accompanying note 281 infra. 
Grounds Department. Ironically, Harvard had recruited those men mainly to expand and upgrade minority group employment.

The dispute, however, quickly encompassed the entire range of university employment practices, particularly those affecting several current construction projects. On November 18 the Harvard black student association, the Organization of Black Unity (OBU), a number of whose members had been active in the Tufts affair, made demands strikingly similar to those made at Tufts. The Harvard students adopted the twenty percent minimum for minority group employment and a number of ancillary provisions, including the student monitor suggestion. In addition, the students demanded that a Worker's Defense League training program be implemented at all university construction sites. ${ }^{90}$

The university, negotiating through law school Professor Archibald Cox, rejected the students' twenty percent demand:

First, the demand is that Harvard promise discrimination in employment. There is no justification for promising black and other non-white workers 20 per cent of the construction jobs, even though a target equal to the proportion of black and other minority workers in the local area is justified. The non-white proportion in the Boston metropolitan area, according to the 1960 census, is 3.4 per cent of the total population. The non-white population of Boston and Cambridge, according to the same source, is 9.3 per cent. . . . Granting that some upwards adjustment may be appropriate because of population changes since 1960 , and also the omission of some Puerto Ricans, still the proportion does not come anywhere near to 20 per cent. Accession to the demand would therefore involve gross and seemingly illegal discrimination.

Second, Harvard cannot promise a 20 per cent figure now, because the promise cannot be performed. Harvard does not control the hiring on construction projects or the conditions imposed by labor unions upon admission to the trade. Harvard has no power to interfere with the contractor's practices upon existing projects. Even in letting new construction contracts, the University's bargaining power is limited because of the many times larger volume of construction elsewhere in the area.

In addition, men with the necessary skills are not presently available. They can be trained, and the University is energetically supporting training programs. ${ }^{100}$

99 See Harvard Univ. News Office, Statement by Harvard University Regarding Discussions with the Organization for Black Unity 2, Dec. 2, 1969 (commentary explaining Harvard's point-by-point response to OBU \& the Harvard-Radcliffe Ass'n of African \& Afro-Am. Students demands).

100 Harvard Univ., Press Release, Dec. 15, 1969. 
The students remained adamant. On December 11, demonstrators occupied University Hall, a central administration building, for the third time since the controversy began. The university obtained a court order against the occupation and ultimately disciplined some of the students involved. It also retained Mr. Clifford Alexander, former Director of the Equal Employment Opportunity Commission, to participate in the negotiation of university construction contracts, and authorized him to veto any contract in which the contractor's affirmative action program did not meet with his approval.

In this context Harvard contracted with Jackson Construction Company for an addition to its Music Building. Instead of incorporating the general language of Executive Order 11246 in the contract, Harvard established nineteen to twenty-three percent as the range for the minimum minority group employment. Harvard's results provide an illuminating basis of comparison for the Tufts strategy.

\section{Postcontractual Compliance Efforts}

The Tufts case study demonstrates the university's practical difficulties in trying to eradicate racial imbalance among the workers on its construction projects after the contracts have been awarded and work started. Tufts tried various methods to correct problems on its dormitory project with meager success. Its postcontractual efforts for integration raise also the question of legal remedies available to a university after awarding a construction contract which merely incorporates the equal employment opportunity clauses required by Executive Order 11246. Both the scope of the contractor's duty under the Order and judicial or administrative enforcement of that duty need be considered.

\section{A. The Scope of the Contractor's Duty Under Executive Order 11246}

Executive Order 11246 imposes upon the contractor the obligation "not [to] discriminate against any employee or applicant for employment because of race, color, religion, sex, or national origin"; the contractor must "take affirmative action to ensure that applicants are employed, and employees are treated during employment without regard to their race, color, religion, sex, or national origin." ${ }^{101}$ The Tufts controversy dramatically demonstrates the present confusion over the scope of this duty. Volpe's affirmative action program, although

101 Exec. Order No. 11,246 §202, 3 C.F.R. 402 (1970), 42 U.S.C. \$2000e (Supp. $\mathrm{V}, 1970)$. 
preliminarily approved by HUD, and although specifying numerous procedural steps for the appointment of an equal employment opportunity officer, posting of notices, and notification of minority groups, failed to provide standards for measuring the effective implementation of this obligation. The particularity of the procedures enabled Volpe to argue that it had complied under the Executive Order simply by following such procedures, despite continued racial imbalance in the work force. Tufts, in turn, argued that this racial imbalance was evidence of noncompliance. Tufts forced the issue by filing suit for a declaratory judgment finding the general contractor in violation of the equal employment opportunity clause.

\section{Administrative Construction and Implementation of the} Contractor's Duty Under Executive Order 11246

The most obvious sources of elucidation of the contractor's duty under Executive Order 11246 are the agencies charged with its enforcement. Unfortunately, the rules in effect during the Tufts controversy set no more specific standards for judging compliance than Volpe's affirmative action program.

Neither Executive Order 10925, which introduced the "affirmative action" phrase, ${ }^{102}$ nor the current Executive Order 11246 explain the term. The President's Committee on Equal Employment Opportunity (PCEEO), established by President Kennedy's 1961 Order, promulgated a set of rules which contain no description of the nature of the obligation. ${ }^{103}$ These rules were superseded on July 1, 1968 by the new OFCC rules which provide:

(a) Requirements of [affirmative action compliance] programs. Each agency or applicant shall require each prime contractor ... and each prime contractor and subcontractor shall require each subcontractor . . . to develop a written affirmative action compliance program for each of its establishments. A necessary prerequisite to the development of a satisfactory affirmative action program is the identification and analysis of problem areas inherent in minority employment and an evaluation of opportunities for utilization of minority group personnel. The contractor's program shall provide in detail for specific steps to guarantee equal employment opportunity keyed to the problems and needs of members of minority groups, including, when there are deficiencies, the development of specific goals and time tables for the prompt achievement of full and equal employment opportunity. . . . 
(b) Utilization evaluation. The evaluation of utilization of minority group personnel shall include the following:

(1) An analysis of minority group representation in all job categories.

(2) An analysis of hiring practices for the past year, including recruitment sources and testing, to determine whether equal employment opportunity is being afforded in all job categories.

(3) An analysis of upgrading, transfer and promotion for the past year to determine whether equal employment opportunity is being afforded. ${ }^{104}$

Although the contractor must set goals and devise timetables, the regulations nowhere define the ultimate objective of "equal employment opportunity." Agency elaborations of these vague requirements offer little help. ${ }^{105}$ For example, HUD's Instructions for Contractors Regarding Affirmative Action Under Executive Order 11246 were applicable in the Tufts situation. This document, like Volpe's affirmative action program, merely requires that the contractor appoint an equal employment opportunity officer, develop an equal employment opportunity program, and recruit from minority groups. ${ }^{106}$

\section{Implications of Title VII of the 1964 Civil Rights Act for the Scope of the Contractor's Duty}

The absence of internal administrative standards for judging the scope of the contractor's duty necessitates a search for standards outside the actual confines of the Order. In particular, because the Executive Order focuses on the terms "discrimination" and "affirmative action," it is appropriate to investigate the use of the identical terms in title VII of the 1964 Civil Rights Act. ${ }^{107}$

10441 C.F.R. $\$ 60-1.40$ (1970).

105 Although Exec. Order No. 11,246 \$201, 3 C.F.R. 402 (1970), 42 U.S.C. $\$ 2000 \mathrm{e}$ (Supp. V, 1970) vests primary rulemaking authority in the Secretary of Labor, the head of each contracting agency must "prescribe regulations for the administration of the order" and for the observance of the OFCC implementing regulations. 41 C.F.R. $\$ 60-1.6(\mathrm{c})$ (1970).

106 U.S. Dep't of Housing \& Urban Development, Form No. 907, Instructions for Contractors Regarding Affirmative Action Under Executive Order 11,246, July 1967.

10742 U.S.C. $\$ \$ 2000$ e to e-15 (1964). Relying on the principle established by Youngstown Sheet \& Tube Co. v. Sawyer, 343 U.S. 579 (1952), it has been argued that the passage of the Civil Rights Act of 1964 preempted executive power in the field of employment discrimination. See Remmert, Executive Order 11,246: Executive Encroachment, 55 A.B.A.J. 1037 (1969). The Youngstozen case established the general principle that, if Congress in comprehensive legislation expressly or impliedly declines to grant the President the authority to deal with a given matter, the President exceeds the constitutional limits of his power when he nevertheless attempts to exercise the denied authority by executive order. Although Executive Order 11246 cannot require conduct which would itself violate title VII, Congress probably did 
a. The Meaning of "Discrimination" Under Title VII

Section 703(a) of the Civil Rights Act provides that: employer-

(a) It shall be an unlawful employment practice for an

(1) to fail or refuse to hire or to discharge any individual, or otherwise to discriminate against any individual with respect to his compensation, terms, conditions, or privileges of employment, because of such individual's race, color, religion, sex, or national origin; or

(2) to limit, segregate, or classify his employees in any way which would deprive or tend to deprive any individual of employment opportunities or otherwise adversely affect his status as an employee, because of such individual's race, color, religion, sex, or national origin. ${ }^{108}$

By making it unlawful for an employer to "fail or refuse to hire," to "otherwise discriminate" against an individual, or to "limit, segregate or classify" employees to "deprive or tend to deprive" individuals of employment opportunities or otherwise "adversely affect" their status as employees because of race, color, religion, sex, or national origin, the title manifests an intention to define discrimination in the broadest possible terms. ${ }^{109}$ Although early judicial decisions under the Act were somewhat inconsistent, ${ }^{110}$ more recent cases ${ }^{111}$ have established a two-step analysis in considering a challenge to a particular

not intend to preempt totally executive power to deal with equal employment opportunity, because the Act itself specifically refers to the concurrent existence of executive orders: $\$ 709$ (d), 42 U.S.C. $\$ 2000 \mathrm{e}-8$ (d) (1964) (employer subject to executive order recordkeeping requirements not required to file additional reports with Equal Employment Opportunity Commission); $\$ 716(\mathrm{c}), 42$ U.S.C. $\$ 2000$ e-15 (1964) (PCEEO specifically named as agency to be invited to conferences convened to familiarize affected groups with rights and obligations created by the Act). See also 110 CoNG. REc. 13652 (1964) (defeat of "Tower Amendment" which would have made title VII preempt executive power).

10842 U.S.C. $\$ 2000 \mathrm{e}-2$ (a) (1964). A similar prohibition with respect to unions is set out in $\$ 703$ (c), 42 U.S.C. $\$ 2000 \mathrm{e}-2$ (c) (1964).

109 Cooper \& Sobol, Seniority and Testing Under Fair Employnent Lawe: A General Approach to Objective Criteria of Hiring and Promotion, 82 HARV. L. REv. 1598, 1612 (1969); see Blumrosen, The Duty of Fair Recruitment Under the Civil Rights Act of 1964, 22 RuTGERS L. REv. 465, 472-75 (1968).

110 Compare Local 53, Heat \& Frost Insulators v. Vogler, 407 F.2d 1047 (5th Cir. 1969) and Dobbins v. Iocal 212, Electrical Workers, 292 F. Supp. 413 (S.D. Ohio 1968) antd Quarles v. Philip Morris, Inc., 279 F. Supp. 505 (E.D. Va. 1968), with United States v. H. K. Porter Co., 296 F. Supp. 40 (N.D. Ala. 1968) and Griggs v. Duke Power Co., 292 F. Supp. 243 (M.D.N.C. 1968), modified, 420 F.2d 1225 (4th Cir.), cert. granted, 399 U.S. 926 (1970) and United States v. Sheet Metal Workers Local 36, 280 F. Supp. 719 (E.D. Mo. 1968), rev'd, 416 F.2d 123 (Sth Cir. 1969).

111 See, e.g., Griggs v. Duke Power Co., 420 F.2d 1225 (4th Cir.), cert. granted, 399 U.S. 926 (1970); United States v. Sheet Metal Workers Local 36, 416 F.2d 123 (8th Cir. 1969); Local 189, Papermakers v. United States, 416 F.2d 980 (5th Cir. 1969), cert. denied, 397 U.S. 919 (1970); Washington v. Baugh Constr. Co., 61 CCH Lab. Cas. $\Uparrow 9346$ (W.D. Wash. 1969). 
employment practice: "first, a determination of the racial impact of the practice, and second, a determination whether any significant adverse racial impact that exists can be adequately justified by non-racial considerations." 112

For example, in Local 189, Papermakers v. United States, ${ }^{113}$ the Fifth Circuit affirmed a district court finding that a seniority and promotional system, although ostensibly based on neutral criteria, violated the Act because past discrimination by the company barring black employees from the seniority unit made the present operation discriminatory. Judge Wisdom summarized the unanimous court's conclusions :

(1) Crown's [the company] job seniority system carries forward the discriminatory effects integral to the company's former employment practices. (2) The safe and efficient operation of the Bogalusa mill does not depend upon maintenance of the job seniority system. (3) To the extent that Crown and the white union insisted upon carrying forward exclusion of a racially-determined class, without business necessity, they committed, with the requisite intent, in the statutory sense, an unfair employment practice as defined by Title VII.114

The court similarly eschewed a test based on the employer's state of mind; Judge Wisdom emphasized the impact of the challenged action rather than the purpose behind it. ${ }^{115}$ The cause of the disadvantage thus does not seem to be determinative. ${ }^{116}$ Whether grounded in a

112 Cooper \& Sobol, supra note 109, at 1671 . This test was articulated by the authors prior to most of the decisions cited in note 111 supra.

113416 F.2d 980 (5th Cir. 1969), cert. denied, 397 U.S. 919 (1970).

$114 I d$. at 997 (emphasis in original).

115 The court reasoned:

Here . . . the conduct engaged in had racially-determined effects. The requisite intent may be inferred from the fact that defendants persisted in the conduct after its racial implications had become known to them. Section 707 (a) demands no more.

Id.

116 Most of the cases decided under title VII, however, have concerned deprivations caused by past or present employer or union motives that are explicitly discriminatory. On the other hand, the court in Griggs v. Duke Power Co., 420 F.2d 1225 (4th Cir.), cert. granted, 399 U.S. 926 (1970), seems to have distinguished between such deprivations and deprivations caused by societal discrimination. There the evidence showed that the company had explicitly discriminated against blacks in the past by restricting them to the laborer's department. Subsequently, the company required workers to have either a high school diploma or minimum test scores for advancement. Blacks hired both before and after the institution of this requirement sued. The court enjoined the "company from imposing the advancement requirement on blacks hired prior to its institution because it perpetuated past explicit discrimination. The court refused to enjoin use of the requirement against blacks subsequently hired despite evidence that the requirement had adverse effects on blacks as a class. The reasoning of the court can be reconciled with the authors' proposition by reading the decision narrowly to hold that "business necessity" justified not only tests measuring "job related" skills, but also tests of general ability. This latter proposition was disputed by Judge Sobeloff in his dissent, id. at 1237, and has not been universally 
prior discriminatory motive or deriving from general societal discrimination either in education or housing, ${ }^{117}$ the employer's violation of title VII should be based upon his incorporation of the disadvantage into subsequent business decisions. ${ }^{118}$

Executive Order 11246 should be construed consistently with this judicial interpretation of the language and meaning of title VII. A contractor should be held to have violated the obligation not to discriminate imposed by the Order if he has used employment practices that, objectively considered, adversely affect minority group workers, unless such adverse effect can be adequately justified by nonracial considerations.

Against this background of title VII, the prohibition of contractor discrimination imposed by Executive Order 11246 assumes more meaning. Under title VII, if a union discriminated against minority group workers in the past and continues to recruit without giving the minority community notice of the extinction of its discriminatory hiring policies, that failure to give notice conceals job opportunities and constitutes discrimination. ${ }^{119}$ The same result should obtain where a union encourages nepotism or requires sponsorship to perpetuate past exclusion whether caused by deliberate act of the union or by the accident of social segregation. ${ }^{120}$ Thus, for the purposes of the Executive Order, a contractor who hires predominantly through union hiring halls, even though minority group referral organizations exist, could be held to be utilizing a discriminatory employment practice if the hiring hall excludes minority group workers by one of the above methods. ${ }^{121}$

accepted. See Arrington v. Massachusetts Bay Transp. Auth., $61 \mathrm{CCH}$ Lab. Cas. II 9375 (D. Mass. Dec. 22, 1969) (general aptitude test for municipal employment held unconstitutional because culturally biased). Moreover, recent cases have drawn no distinction between the causes of the deprivation. E.g., Gregory v. Litton Systems, Inc., $63 \mathrm{CCH}$ Lab. Cas. $\mid 9485$ (C.D. Cal. 1970) ("no arrest record" requirement held violative of title VII because blacks arrested more frequently than whites).

117 Cf. Gaston County v. United States, 395 U.S. 285 (1969) (refusal to approve voter literacy test under the Voting Rights Act of 1965 because of the inherent inferiority of education in segregated schooling).

118 Cooper \& Sobol, supra note 109, at 1669-73.

119 See United States v. Sheet Metal Workers Local 36, 416 F.2d 123, 137-40 (8th Cir. 1969).

120 See Local 53, Heat \& Frost Insulators v. Vogler, 407 F.2d 1047, 1054 (5th Cir. 1969). See also Blumrosen, supra note 109, at 476-79; Kaplan, Equal Justice in an Unequal World: Equality for the Negro-The Problem of Special Treatment, 61 Nw. U.L. REv. 363, 368-69 (1966).

121 Cf. Sovern, supra note 40, at 154. The Department of Labor now takes this view. In its recent "Philadelphia Plan" the Department states that if a contractor fails to meet minority employment goals "[i]t is no excuse that the union with which the contractor has a collective bargaining agreement failed to refer minority employees." 2 CCH EMIP. PRAC. GUIDE $\pi 16,175$, at 7153 (June 27, 1969). See also Weiner v. Cuyahoga Community College Dist., 19 Ohio St. 2d 35, 249 N.E.2d 907 (1969), cert. denied, 396 U.S. 1004 (1970). 
Volpe's hiring practices may well have violated this standard: certainly a statistical imbalance in the work force has probative weight in such a determination. ${ }^{122}$

\section{b. The Meaning of "Affirmative Action" Under Title VII}

In other contexts "affirmative action" has come to mean remedial action to overcome the effects of a specific evil. ${ }^{123}$ Title VII also employs the term in its remedial sense. Section $706(\mathrm{~g})$ provides that, once a violation is found, the courts not only may enjoin that violation, but may "order such affirmative action as may be appropriate." ${ }^{24}$ This provision has provided a mandate to the courts to insist on corrective devices that not only eliminate future discrimination, but also remedy the effects of past discrimination. For example, in Local 53, Heat \& Frost Insulators $v$. Vogler, ${ }^{125}$ the district court found that the union local had engaged in exclusionary and nepotistic policies which discriminated on the grounds of race and national origin. To correct the adverse effects of these practices, the district court ordered a system of "alternating white and negro referrals" until objective referral procedures could be devised and implemented. Affirming, the Fifth Circuit ruled that the relief was appropriate "affirmative action" to eliminate the present effects of past discrimination and to prevent future discrimination. ${ }^{126}$ Similarly, in Washington $v$. Baugh Construction Co., ${ }^{127}$ in which the evidence suggested that the unions had refused to refer minority group workers to a contractor engaged in university construction, the court ordered the unions to refer minority group workers presented by the university and to begin implementing an "apprenticeship outreach" program which was being established in

122 Proof largely dependent upon probabilities has been accepted by the Supreme Court in both the jury selection and school cases. E.g., Sims v. Georgia, 389 U.S. 404 (1967) ; Jones v. Georgia, 389 U.S. 24 (1967). Estimation of how many of a district's blacks meet the relatively simple standards imposed upon jurors, however, is far easier than calculation of the number of blacks in an area competent to perform jobs of a certain difficulty. Recognizing this problem, several recent cases have nevertheless sanctioned the use of statistics in demonstrating employment discrimination. E.g., EEOC v. Plumbers Local 189, 62 CCH Lab. Cas. 19434 (S.D. Ohio 1970) ; Penn v. Stumpf, 62 CCH Lab. Cas. 9404 (N.D. Cal. 1970); Dobbins v. Local 212, Electrical Workers, 292 F. Supp. 413, 445 (S.D. Ohio 1968). See also Comment, Enforcement of Fair Employment Under the Civil Rights Act of 1964, 32 U. CHI. L. REV. 430 (1965).

123 See, e.g., NLRB v. Strong Roofing \& Insulating Co., 393 U.S. 357 (1969) (construing National Labor Relations Act $\$ 10(c), 29$ U.S.C. $\$ 160$ (c) (1964)); Phelps Dodge Corp. v. NLRB, 313 U.S. 177 (1941) (construing the same provision)' In the area of school desegregation, a recent case has held that the states are constitutionally compelled "to take affirmative action to reorganize their school systems by integrating the students, faculties, facilities, and activities." United States v. Board of Educ., 372 F.2d 836, 862 (5th Cir. 1966), cert. denied, 389 U.S. 840 (1967).

12442 U.S.C. $\$ 2000 \mathrm{e}-5$ (g) (1964).

125407 F.2d 1047 (5th Cir. 1969).

126 Id. at 1055 .

12761 CCH Lab. Cas, 19346 (W.D. Wash. 1969). 
the area. $^{128}$

"Affirmative action" under Executive Order 11246 should be construed analogously. As long as a contractor's hiring practices are not of themselves discriminatory, he can comply with the affirmative action obligation simply by following the procedural guidelines promulgated by the enforcing agency or specified in his approved affirmative action program. But if the contractor's employment practices are found to be discriminatory, he must not only follow those procedural requisites but also take substantive steps to overcome the effects of the discrimination. This will often mean employment procedures that are not strictly colorblind.

A similar approach has been followed in those cases in which OFCC has negotiated supplementary agreements specifically dealing with the contractor's obligation under the Executive Order, ${ }^{129}$ and in the one reported noncompliance case which has proceeded through a hearing to a decision by the Secretary of Labor. The latter, In re Allen-Bradley Co., ${ }^{130}$ involved a manufacturer of electrical and electronic equipment. It had an overwhelmingly white work force, largely the result of the discontinued practice of giving preference to applicants who were friends and relatives of employees. The "affirmative action" demanded by OFCC, and accepted as appropriate by the hearing panel and the Secretary of Labor, required the company to abandon its exclusive reliance on walk-in applicants for jobs, to take steps to broaden its recruitment base by consulting employment agencies with a substantial black clientele, and to try to change its image in the black community as a discriminatory employer.

\section{Conclusion}

The Tufts case study demonstrates that the insertion of an "affirmative action" obligation in a construction contract and the prescription of drastic sanctions for noncompliance will be ineffective without a specific definition of compliance. Executive Order 11246 and the regulations promulgated thereunder do not by themselves explain the obligations of a contractor. Nevertheless, examining the context of title VII exposes a basis for imposing concrete obligations once an enforcement agency or court has found discrimination. Hence, although it would obviously be more desirable to prescribe specific standards for compliance in a precontractual setting, relief might be

$128 I d$. at 6913.

120 See Cooper \& Sobol, supra note 109, at 1630-31.

130 [Aug. 1968-Apr. 1969 Transfer Binder] CCH LAB. L. REP. If 8065 (OFCC Dec. 17, 1968), aff'd, [Aug. 1968-Apr. 1969 Transfer Binder] CCH LAB L. REP. đ 8070 (Sec'y of Labor, Jan. 16, 1969). 
possible if a university could raise the issues before an administrative or judicial tribunal.

\section{B. Administrative Relief}

Despite the command of Executive Order 11246, backed by severe sanctions, ${ }^{131}$ that grantees of federal construction funds "assist and cooperate actively" with the administering agency and the Secretary of Labor in obtaining the compliance of contractors with the obligations imposed under the Order, ${ }^{132}$ the administrative process is incapable of responding to university action.

\section{University Standing to Initiate Agency Process}

\section{a. Formal Procedures}

The regulations implementing the Order place primary responsibility for securing compliance upon the agency administering the grant. ${ }^{133}$ Before a contract award can be made, the agency's contract compliance officer must review "the available information relative to the prospective prime contractor's equal opportunity compliance status." ${ }^{134}$ This initial review is necessarily confined to the past performance of the contractor and to his ability to fulfill the nondiscrimination and affirmative action requirements of the contract. ${ }^{135}$

After the contract award, the "compliance agency" 136 has continuing responsibility for overseeing the contractor's performance. The regulations require the compliance agency to have a regular program for ordinary compliance reviews as well as for reviews in response to "any special requests or instructions of" the OFCC Director. ${ }^{137}$ There

131 A grantee failing to comply with the Order may lose both its current federal funds and its eligibility for future federal funds. Exec. Order No. 11,246 §303(b), 3 C.F.R. $408-09$ (1970), 42 U.S.C. \$2000e (Supp. V, 1970).

132 Id. $\$ 301,3$ C.F.R. 408 (1970), 42 U.S.C. $\$ 2000$ e (Supp. V, 1970).

13341 C.F.R. $\$ 60-1.6(a)$ (1970).

$134 I d . \S 60-1.6(\mathrm{~d})(2)$.

135 See id. $\$ 60-1.29$ (a) (Director may request preaward compliance review to determine whether contractor can comply with provisions of the equal opportunity clause).

${ }^{136}$ The Director of the OFCC selects the compliance agency on a "geographical industry or other basis." Id. $\S 60-1.3(\mathrm{~d})$. In the absence of a specific designation by the Director, the compliance agency is ordinarily the grantor agency providing the largest share of the funds for the project in question. See id. $\$ \$ 60-1.3$ (d) (1)(4).

${ }^{137}$ Id. $\S 60-1.20$ (c). The compliance review is designed

to determine if the prime contractor or subcontractor maintains nondiscriminatory hiring and employment practices and is taking affirmative action to ensure that applicants are employed and that employees are placed, trained, upgraded, promoted, and otherwise treated during employment without regard to race, color, religion, sex, or national origin.

Id. $\S 60-1.20(\mathrm{a})$. 
is no provision for grantee initiation of the compliance review process; rather, the compliance review scheme is an administrative monitoring mechanism which the agencies must initiate. The timing and thoroughness of compliance reviews are largely discretionary, exercised, necessarily, within the limitations of the agency's staff and funds.

By contrast, the procedure for employees or applicants for employment aggrieved by discrimination is well-defined. The regulations provide that "any employee of any contractor" may file with OFCC or the administering agency "a complaint of alleged discrimination in violation of the equal opportunity clause." ${ }^{138}$ Significantly, neither the Order nor the regulations provide for grantee initiation of the complaint process. ${ }^{139}$

Thus, under the formal procedures of the Executive Order, a university as a federal grantee has no standing to initiate agency process. A university has a right to participate in agency proceedings only if charged with failure to fulfill its duties under the Order. ${ }^{140}$ This scheme is not unusual. Despite a general broadening of the law of judicial standing, ${ }^{141}$ the standing of private parties to initiate agency action remains largely discretionary, depending upon the particular statutory scheme. ${ }^{142}$ Only when agency action already initiated

$13 \$$ Id. $\$ 60-1.21$; see id. $\$ \$ 60-1.22$ to -1.24 . See also Exec. Order No. 11,246 $\$ 206($ b), 3 C.F.R. 405 (1970), 42 U.S.C. $\$ 2000$ e (Supp. V, 1970).

130 The university might rely upon a minority worker to institute action under the Order, but if the complaint is based upon a failure to recruit minority workers actively it may be difficult to find a worker who could convincingly allege discrimination.

Similar problems detract from the utility of instituting a complaint with EEOC under 42 U.S.C. $\$ 2000$ e-5 (1964). Further, the EEOC procedure-which must be exhausted before judicial action may be sought-is replete with delays and ineffective remedies and is limited to "conference, conciliation, and persuasion." Id. $\$ 2000 \mathrm{e}-5$ (a). See generally Note, Discrimination in Employnent and Housing: Private Enforcement Provisions of the Civil Rights Acts of 1964 and 1968, 82 HARV. L. REv. 834 (1969) ; Comment, $A$ Primer to Procedure and Remedy Under Title VII of the Civil Rights Act of 1964, 31 U. PITT. L. REv. 407 (1970). But cf. H.R. 10065, 89th Cong., 2d Sess. (1966) (amendment of title VII empowering EEOC to issue cease and desist orders and to order appropriate "affirmative action").

An alternative procedure, also dependent upon initiation by a minority complainant, would require an allegation of a violation of the duty of fair representation under the National Labor Relations Act. See NLRA \&\& S(b) (1) (A), (b) (2), (b) (3), 29 U.S.C. $\$ \$ 158$ (b) (1) (A), (b) (2), (b) (3) (1964); Vaca v. Sipes, 386 U.S. 171 (1967) (fair representation before the courts); Brotherhood of R.R. Trainmen v. Howard, 343 U.S. 768 (1952); Local 12, Rubber Workers v. NLRB, 368 F.2d 12 (5th Cir. 1966); Miranda Fuel Co., 140 N.L.R.B. 181 (1962), enforcement denied, 326 F.2d 172 (2d Cir. 1963). See generally SovERn, supra note 40, at 143-75. A more novel approach to employee complaint coverage under the NLRA was recently sanctioned in United Packinghouse Workers v. NLRB, 416 F.2d 1126 (D.C. Cir. 1969 ), in which the court held racial discrimination to be a per se violation of NLRA \$ 8 (a) (1), 29 U.S.C. \$ 158 (a) (1) (1964).

140 See Exec. Order No. 11,246 \& 303 (c), 3 C.F.R. 409 (1970), 42 U.S.C. \$2000e (Supp. V, 1970).

141 See, e.g., Association of Data Processing Service Organizations, Inc. v. Camp, 397 U.S. 150 (1970); Office of Communication of the United Church of Christ v. FCC, 359 F.2d 994 (D.C. Cir. 1966); Davis, The Liberalized Law of Standing, 37 U. CHI. L. REv. 450 (1970).

$1421 \mathrm{~K}$. Davis, Administrative Iaw Treatise $\$ 4.07$ (1958); Jaffe, The Individual Right to Imitiate Administrative Process, 25 Iowa L. REv. 485 (1940). 
threatens adverse consequences does a party have a right to a hearing in the agency proceedings. ${ }^{143}$

Although OFCC or the compliance agency should have discretion in determining whether to act, ${ }^{144}$ the Order and regulations should be modified to permit grantee initiation of agency process. The grantee's obligation to "assist and cooperate actively" with the administering agency cannot be fulfilled if the grantee has no effective way to secure contractor compliance. And a grantee in Tufts' position certainly has an interest in contractor compliance when faced with the disruption of its construction by students or labor.

Rather than seek direct administrative intervention against the contractor for noncompliance, the university could pursue alternative relief under the Administrative Procedure Act's rulemaking or declaratory order provisions. Section 4(e) insists that every agency give any "interested person the right to petition for the issuance, amendment, or repeal of a rule." 145 The university might seek concrete compliance standards for the affected area, modeled, for example, after the Philadelphia Plan. ${ }^{146}$ But an agency need not act on a petition under section 4(e), and even then section 4(a) exempts from section 4(e) any "matter relating . . . to public property, loans, grants, benefits, or contracts." 147

The declaratory order "to . . . remove uncertainty" authorized by section 5 (d) ${ }^{148}$ promises easier relief. As opposed to a proceeding by an administrative complaint against the contractor, the university's posture in seeking a declaratory order seems sufficient to satisfy agency standing. ${ }^{149}$ Viewing the declaratory order as an administrative parallel to a declaratory judgment, ${ }^{150}$ the university can characterize its

143 See, e.g., Londoner v. Denver, 210 U.S. 373 (1908).

144 See Jaffe, supra note 142 , at 530.

1455 U.S.C. $\$ 553(\mathrm{e})$ (Supp. V, 1970).

146 Text accompanying notes $216-27$ infra.

1475 U.S.C. \$ $553($ a) (2). See generally Bonfield, Public Participation in Federal

Rulemaking Relating to Public Property, Loans, Grants, Benefits, or Contracts, 118

U. PA. L. REv. 540 (1970).

1485 U.S.C. $\$ 554$ (e) (Supp. V, 1970).

149 See id. The section applies only in cases of "adjudication required by statute to be determined on the record after opportunity for an agency hearing." Id. \$ 554(a). Although there is no statutory requirement of adjudication in the case of determinations of grantee compliance with Executive Order 11246, the Order does provide that "[i]n no case shall action [imposing administrative sanctions] be taken with respect to an applicant . . . without notice and opportunity for hearing before the administering department or agency." Exec. Order No. 11,246 \$303(c), 3 C.F.R. 409 (1970), 42 U.S.C. $\$ 2000 \mathrm{e}$ (Supp. V, 1970). And it has been held that the Order "is to be accorded the force and effect of statutory law." United States v. United Papermakers \& Paperworkers Local 189, 282 F. Supp. 39, 43 (E.D. La. 1968), aff'd, 416 F.2d 980 (5th Cir. 1969). See also Farkas v. Texas Instrument, Inc., 375 F.2d 629, 632 n.1 (5th Cir.), cert. denied, 389 U.S. 977 (1967).

150 The American Bar Association, through its Subcommittee on Declaratory Orders of its Administrative Process Committee, has stated that declaratory orders are a useful and obvious administrative parallel to declaratory judgments. Comment, Declaratory Orders-Uncertain Tools to Remove Uncertainty, 21 AD. L. REv. 257, 262 (1969). 
request as a defense to an anticipated action against it by the agency for failure to assure nondiscrimination and affirmative action on its construction project.

The status and availability of declaratory orders are uncertain in most agencies, ${ }^{151}$ including OFCC, and their utility is questionable. The issuance of such orders is in the sound discretion of the agency concerned, ${ }^{152}$ and in the absence of OFCC rules for declaratory orders, a grantee cannot know what facts or circumstances would appeal to its discretion or to the compliance agency's. More significantly, entertainment of the request would not necessarily afford the university the relief it desires. The agency can avoid the university's problem by continuing funding without investigating possible violations by the contractor. Such a result would not satisfy students agitating for more minority group employment and would not further the university's ultimate goal of integrating the construction industry.

\section{b. Informal Procedures}

Despite the problems in formal initiation of agency process, the Tufts experience indicates it is not difficult to trigger the initial investigatory phase of a compliance review by informal request. But this procedure is haphazard at best, and the Tufts case study shows how difficult it is to expedite the investigation and to require the agency to make findings constituting a basis for a formal hearing. HUD investigators assured the university that the entire procedure could be concluded, through the hearing stage to final determination, within 120 days of the start of the investigation. Nevertheless, although HUD responded promptly to the request for a compliance review, its investigation languished from mid-November until the project was completed in early July. No findings were ever issued nor was a formal conciliation process undertaken, although the investigation itself evidently exerted indirect pressure on the contractor to recruit more vigorously among minority groups. ${ }^{153}$

\section{The Inadequacy of Agency Process}

Even though a university may be able to initiate agency process informally, the inadequacy of that process prevents effective enforcement. Both formally and informally initiated compliance proceedings begin with an investigation by the agency with "primary responsibility" for compliance. ${ }^{154}$ Although cancellation of present funding and in-

151 Id. 258-62.

1525 U.S.C. $\$ 554(\mathrm{e})$ (Supp. V, 1970). The ABA subcommittee supported the passage of S. 518, 90th Cong., 1st Sess. \$ $6(\mathrm{k})$ (1967), which provided for mandatory agency action on petitions for declaratory orders. Comment, supra note 150, at 264 .

153 From November 4 to November 18, the number of black workers increased from 7 out of a work force of 99 to 13 out of a work force of 90 .

154 See 41 C.F.R. $\$ 60-1.24$ (b) (1970). 
eligibility for future funding are the ultimate sanctions, ${ }^{155}$ the Order provides informal procedures-"conference, conciliation, mediation, or persuasion"- as the preferred means for securing compliance. ${ }^{156}$ The regulations state that when an agency's investigation indicates the existence of an apparent violation of the nondiscrimination provisions, "the matter should be resolved by informal means whenever possible." 157 Informal resolution is ultimately reviewable by the OFCC Director, ${ }^{158}$ but he may also assume jurisdiction at any stage of an agency proceeding, whether formal or informal, when he considers it "necessary or appropriate to the achievement of the purposes of the Order." 159

The overlapping of this concurrent jurisdiction has created confusion rather than rigorous enforcement. The grantee does not know which agency to consult at any particular stage of the proceeding; ${ }^{180}$ the contractor is uncertain of its contractual obligations because OFCC and other agencies' standards for affirmative action may differ; ${ }^{161}$ and the agencies themselves seem impelled to pass on responsibility.

The decision to vest primary responsibility in the grantor agency is of doubtful wisdom. Tone, rigor, and specificity of the affirmative action program depend primarily on the initial review. Yet the grantor agency is basically interested in implementing its construction program. From its point of view, the nondiscrimination objectives of the Order are secondary, while delays and other problems potentially resulting from the cancellation of a contract make the agency reluctant to impose sanctions. ${ }^{162}$ The result is often an ineffective affirmative action program like Volpe's.

Finally, the very severity of the sanction of cancellation of funding insures its infrequent use. Aside from a reluctance to punish contractors so harshly, the Government will hesitate to cause delay in

155 Exec. Order No. 11,246 §§ 209 (a) (5)-(6), 3 C.F.R. 406 (1970), 42 U.S.C. $\S 2000 \mathrm{e}$ (Supp. V, 1970).

156 Id. $\$ 209$ (b), 3 C.F.R. 406 (1970), 42 U.S.C. $\$ 2000$ e (Supp. V, 1970).

15741 C.F.R. $\$ 60-1.24(\mathrm{c})(2)$ (1970).

158 Id. $\$ \$ 60-1.24$ (c) (1)-(2). The Director's authority is delegated to him by the Secretary of Labor, who is ultimately responsible for compliance with the Order. Exec. Order No. 11,246 \&201, 3 C.F.R. 402 (1970), 42 U.S.C. $\$ 2000$ e (Supp. V, 1970).

15941 C.F.R. $\$ 60-1.25$ (1970).

160 Tufts experienced this confusion when it first attempted to contact the appropriate regional office. The agencies sent a team of OFCC and HUD officials and even used an HEW compliance officer from Boston. For a discussion of confusion created in other areas by multi-agency control, see Rodgers, The Persistent Problenn of the Persistent Pesticides: A Lesson in Environmental Law, 70 CoLUM. L. Rev. 567 (1970).

161 Compare U.S. Dep't of Housing \& Urban Development, Form No. 907, Instructions for Contractors Regarding Affirmative Action Under Executive Order 11246, July 1967, with 41 C.F.R. $\$ \$ 60-1.40$ to -1.42 (1970).

162 See Note, supra note 1, at 602-03. See also Jones, Federal Contract Compliance in Phase I-The Dazening of the Age of Enforcement of Equal Employment Obligations, 4 GA. L. REv. 756 (1970). 
needed construction, blacklist large contractors whose services are required, or injure workers by indirectly depriving them of employment. The enforcement agencies are forced to rely upon informal settlement encouraging both long delays as experienced by Tufts, and "soft settlements." 163

With inadequate staff, ${ }^{164}$ even the best administrative scheme must fail to provide meaningful enforcement in terms of a significant increase in the number of minority group workers in construction. The present administrative arrangement compounds the staffing problems. Unequivocal provision for grantee standing, consolidation of enforcement activities in OFCC, and perhaps a broader range of sanctions would at least on paper constitute an effective scheme pending the supplementation of existing funds for staff. Meanwhile, a university can only attempt to obtain judicial relief.

\section{Judicial Relief}

The interests of a university attempting to enforce the contractor's duties under Executive Order 11246 are dissimilar from those of the usual plaintiff in a contract action. A plaintiff normally asserts that the defendant owes him an unfulfilled duty and demands satisfaction of that duty through damages or equitable relief. But the contractor's unfulfilled duty is at best only indirectly owed to the university. The primary beneficiaries of the contractor's duties under the Order are the minority group workers, and they will not be parties to the litigation. ${ }^{165}$ Thus the university faces two difficult tasks. First, it must characterize its legal interest under the Order to give it standing to sue the parties capable of either fulfilling or enforcing the duties specified in the Order. Second, the university must demand a form of relief which will benefit not only its own interests but also those of the minority group workers.

\section{Action Against the Agency}

Executive Order 11246 charges the government agency administering the federal funds for the project with primary responsibility for

163 Cf. Sovern, supra note 40 , at 48.

104 During the Tufts controversy, OFCC had no compliance officers in New England and only one in New York.

165 Institution of judicial action under the Order on behalf of minority group workers allegedly discriminated against would be infeasible. First, the university would have to find workers who could allege discrimination. Those workers must exhaust their administrative remedies under procedures outlined by OFCC. 41 C.F.R. $\$ \$ 60-1.21$ to $-1.32(1970)$. This involves significant delay, undercutting the possibility of gaining an order affecting the contractor's practices on the construction in question. Second, even if administrative procedures could be exhausted with sufficient speed, courts have held that a worker alleging discrimination fails to state a cause of action against the contractor because the administrative remedies are available and the agency action final. See, e.g., Farkas v. Texas Instrument, Inc., 375 F.2d 629, 633 (5th Cir.), cert. denied, 389 U.S. 977 (1967), discussed at text accompanying note 204 infra. Similar difficulties would exist in a title VII action on behalf of minority workers. See note 139 supra. 
compliance. ${ }^{166}$ Thus a university's first logical step in an effort to enforce the Order is to attempt to compel the agency to fulfill its responsibilities.

The available judicial action, however, will not place the university in an adversary position relative to the government agency regarding the agency's duty to obtain the contractor's compliance. Although the federal district courts have jurisdiction over actions to compel a federal agency to perform its duty, that jurisdiction exists only when the duty in question is owed to the plaintiff. ${ }^{107}$ Because the Order is intended to benefit primarily minority group workers and because no provision is made for grantee initiation of complaints of contractor noncompliance, ${ }^{168}$ a court is likely to find that the agency's duty to obtain contractor compliance is owed solely to the minority group workers. Thus the university cannot utilize this mandamus jurisdiction.

The university can place itself in an adversary relationship with the agency only with respect to issues peripheral to the agency's enforcement duty. The university can, for example, sue for a declaratory judgment ${ }^{169}$ that it had fulfilled its obligation to "assist and cooperate actively" with the agency in obtaining the contractor's compliance ${ }^{170}$ and hence is entitled to payment of its grant. But the doctrines of ripeness ${ }^{171}$ and sovereign immunity ${ }^{172}$ would probably render such an

${ }_{168}$ Exec. Order No. $11,246 \$ 301-04,3$ C.F.R. $407-09$ (1970), 42 U.S.C. $\$ 2000 e$ (Supp. V, 1970).

16728 U.S.C. $\$ 1361$ (1964).

168 Text accompanying notes 137-43 supra. Both Exec. Order No. 11,246 §206 (b), 3 C.F.R. 405 (1970), 42 U.S.C. $\$ 2000$ e (Supp. V, 1970) and the regulations implementing the Order, 41 C.F.R. $\$ 60-1.21$ (1970), provide only for employee initiation of complaints of discrimination against contractors.

16928 U.S.C. $\$ 2201$ (1964).

170 Exec. Order No. 11,246 §301, 3 C.F.R. 407 (1970), 42 U.S.C. §2000e (Supp. $\mathrm{V}, 1970)$.

${ }^{271}$ There are several tests for ripeness within the declaratory judgment context. The university obviously fails to meet the most stringent standard, the accrual of a coercive cause of action to one of the parties with respect to the contested issue. Developments in the Lare-Declaratory Jidgments-1941-1949, 62 HARv. L. REv. 787, 794 (1949) [hereinafter cited as Developments]. No coercive action has accrued to the university because it has not been denied funds. Nor has an action accrued to the agency, for it is required by the Executive Order to grant opportunity for a hearing before stopping payment. Exec. Order No. 11,246, \$303(c), 3 C.F.R. 409 (1970), 42 U.S.C. \$2000e (Supp. V, 1970). Moreover, it is questionable whether the contemplated litigation even meets the more liberal standard of relative certainty that coercive litigation will eventually ensue between the same parties. Developments 794. In similar situations, actions have been held premature when the defendant did not actually threaten to bring a judicial action. See Eccles v. Peoples Bank, 333 U.S. 426 (1948) (no indication that defendant would exercise its alleged right to expel petitioner from Federal Reserve System); Developments 795 .

${ }^{172}$ For jurisdictional purposes, declaratory actions are judged by the form of the action which would necessarily be brought were the declaratory procedures unavailable. In this case the coercive form of the declaratory suit would be an action to compel payment of the grant. But sovereign immunity traditionally bars actions against officials for specific relief. See Larson v. Domestic \& Foreign Commerce Corp., 337 U.S. 682, 703-05 (1949) - H.M. H. HART \& H. WeChSLER, THE FEDERAL COURTS AND THE FEDERAL SYSTEM 1177 (1953).

The possibility of avoiding the sovereign immunity difficulty through an action under a special statutory exemption is slight. The amount of the university's potential 
action nonjusticiable. Even if the suit were allowed and judgment awarded to the university, the university would not necessarily gain the desired relief. The agency could frustrate the university's objective of increasing minority employment by conceding that the university was entitled to payment, without initiating an investigation of the contractor.

\section{Action Against the Contractor}

Judicial action against the contractor raises several strategic issues. The university should first consider whether the initiation of judicial action or taking the stronger step of suspending construction and defending against the contractor's action for damages by raising the claim of contractor noncompliance is more effective. The black students at Tufts suggested suspension, and most student bodies would probably support such direct action enthusiastically. But the liabilities of suspension almost surely outweigh the potential public relations benefits. The university's building program would be delayed, denying it necessary facilities and exposing it to the risk of higher construction costs in the future. More important, the university would lack precedential support in defending the contractor's damages suit. Standards for determining noncompliance with the Order are ill-defined. Even if the university could prove contractor noncompliance, a court might still hold that such noncompliance did not sufficiently impair the value of the contract so as to justify suspension of the entire contract by the university. ${ }^{173}$ Moreover, failure in such a suit would greatly increase the eventual costs of the construction. Hence, absent further judicial or administrative clarification of the law under the Order, suspension of the construction is ill-advised.

claim against the agency creates the problem. The Tucker Act grants jurisdiction to the district courts for claims against the United States founded upon any regulation of an executive department, or upon any express or implied contract with the United States. 28 U.S.C. \$1346(a) (2) (1964). But unless the university has already been paid a large portion of the agency grant, the amount in question would almost surely exceed the Tucker Act's $\$ 10,000$ limitation. This would remit the university to the jurisdiction of the Court of Claims under the statute granting it jurisdiction "to render judgment upon any claim against the United States founded . . . upon ... any regulation of an executive department . . . Id. $\$ 1491$. This remission deprives the university of its cause of action, however, because the Supreme Court has recently relied on the historical restriction of Court of Claims remedies to money judgments to deny that court jurisdiction to render declaratory judgments. United States y. King, 395 U.S. 1 (1969). Hence, a statutory exemption from the sovereign immunity bar appears unavailable.

173

Although breach to any extent of any promise in a contract gives rise to a cause of action ... a slight breach will not necessarily end further duties of the injured person for the performance of the contract.

11 S. Williston, Treatise on the Law of Contracts $\$ 1292$, at 8 (3rd ed. 1968). Because the contractual provisions imposed by the Order are not bargained for by either the contractor or the university, text following note 200 infra, and because they are intended to benefit minority group workers rather than the parties to the contract, a court would probably find that a contractor's noncompliance with them was a "slight breach" not justifying termination by the university. 
The university, however, can avoid the risk of potential liability. Instead of suspending work and becoming the defendant in the contractor's ensuing action for damages, the university can take the position of a plaintiff by demanding declaratory and equitable relief. The university might, for example, join an action for a declaratory judgment regarding the contractor's compliance with a demand for equitable relief ${ }^{174}$ in the form of an injunction against further racial discrimination and of specific performance of the contractor's affirmative action duty as defined by the title VII analogies. ${ }^{175}$ Even though the equitable relief were denied, a favorable declaratory judgment might indirectly support subsequent demands for changes in the contractor's employment policies or might provide a basis for suspension of the project.

The prayer for declaratory relief might be phrased in several ways. The university can request a declaration that the contractor's actions did not meet the specifications of Executive Order 11246 as embodied in the contract. Or, to test its right to take more drastic measures, it could request a declaration that it would not violate the contract by suspending work for the contractor's failure to meet its obligations.

Another strategic problem is deciding whether to bring suit in state or federal court. A federal court appears to be more appropriate for adjudicating standards under an ambiguous executive order, and declaratory procedures may be unavailable in the courts of certain states. But difficult jurisdictional problems may ultimately deny federal jurisdiction and preclude effective relief. In any event, a state court must enforce any duty under federal law actually owed to the university. ${ }^{176}$ For purposes of the discussion in this Article, however, the university will be assumed to have chosen the federal forum, thus avoiding the peculiar procedural rules of any given state and providing the analysis with as wide an application as possible.

\section{a. Federal Jurisdiction}

The Federal Declaratory Judgment Act states that

[i]n a case of actual controversy within its jurisdiction .. . any court of the United States, upon the filing of an appropriate pleading, may declare the rights and other legal relations of any interested party seeking such a declaration, whether or not further relief is or could be sought. ${ }^{177}$

The Act's requirement of an "actual controversy" and "jurisdiction" points out two issues raised by the proposed litigation. relief).

17428 U.S.C. $\$ 2202$ (1964) (other remedies may be coupled with declaratory

175 These analogies are developed in the text accompanying notes 107-30 supra.

176 See Testa v. Katt, 330 U.S. 386 (1947).

17728 U.S.C. $\$ 2201$ (1964). 


\section{(i) "Actual Controversy"}

The university's suit for declaratory relief regarding its rights against the contractor should be found to satisfy the test of justiciability requiring "relative certainty of ultimate coercive litigation." 178 If the university sought a declaration that suspension of work on the project would not violate the contract, ultimate coercive litigation would be relatively certain at least in one sense, because suspension would almost surely result in an action for damages against the university. But the university must also demonstrate its actual intent to suspend the contract for the contractor's noncompliance. ${ }^{179}$

Although difficult to prove, the university's intent is not merely hypothetical. Committed by contract and perhaps by its public statements to the goal of increasing minority group employment and under pressure from its students to further that goal, the university has the requisite intent to engage in a "definite, proposed course of conduct" 180 - suspension of the contract for noncompliance. Its unwillingness to act in the absence of a declaratory order defining the probable legal consequences of a suspension should not preclude the granting of declaratory relief, for the university should not be forced to act at its peril to secure compliance with the contract. ${ }^{181}$

"Within its Jurisdiction"

\section{(a) Amount in Controversy}

To base jurisdiction on either diversity of citizenship ${ }^{182}$ or the existence of a federal question ${ }^{183}$ requires that the "amount in controversy" exceed 10,000 dollars.

Courts look to the value of the contractual rights whose validity is questioned to determine the amount in controversy in a declaratory

178 Developments 795. See generally note 171 supra.

173

[A] declaration as to plaintiff's right to perform an act, or as to the consequences of his action, is likely to be refused if a sufficiently definite intent to perform the act has not been manifested.

Developments 795 (footnote omitted).

180

[W] here the requirements of justiciability are otherwise met, a party to a contract should be able to secure a declaratory judgment as to the legal effect of a definite, proposed course of conduct.

6A J. Moore, Federal Practice If 57.12, at 3067 (2đ ed. 1966) (footnote omitted). 181 Id. $\llbracket 57.12$.

18228 U.S.C. $\$ 1332$ (1964). Because the requirement of diversity of citizenship is obviously satisfied whenever the university and the contractor are from different states, subsequent discussion deals only with the problems arising from an assertion of federal question jurisdiction.

183 Id. $\$ 1331$. 
judgment action. ${ }^{184}$ Insofar as the university seeks a declaration that the entire contract is invalid because of the contractor's noncompliance with the Order, the amount in controversy should be found to exceed 10,000 dollars, as most federally funded construction contracts are likely to involve sums substantially greater than that amount. But an action to secure only an injunction against contractor discrimination and specific performance of the contractor's duty of affirmative action under the Order would satisfy the jurisdictional amount only under certain circumstances. ${ }^{185}$

In actions for specific performance, the "value of the object to be gained by the plaintiff" ${ }^{186}$ determines the amount in controversy. Because the contractual provisions forbidding discrimination are not "bargained for" by the university and because they are intended to benefit only the minority group workers, a court could readily conclude that the actual monetary value to be gained by the university from the contractor's compliance is less than the requisite amount. But in actions to enjoin a contract violation threatening one party with irreparable damage, courts have evidenced a willingness to look beyond the immediate value of the contractual rights in question to the potential damages resulting from noncompliance in order to determine whether the jurisdictional amount is satisfied. ${ }^{187}$ Threatened with student or labor disruption of its construction projects or its general

184 See Freedman v. Zurich Ins. Co., 264 F. Supp. 550, 551 (W.D. Pa. 1967); Empire Box Corp. v. Willard Sulzberger Motor Co., 104 F. Supp. 762, 766 (D.N.J. 1952).

185 Assuming that the prayer for declaratory judgment satisfied the requirement of $\$ 10,000$ in controversy, a federal court would have jurisdiction to hear alternative claims for relief arising out of the same controversy, although they did not in themselves satisfy the jurisdictional amount. See Shappirio v. Goldberg, 192 U.S. 232 (1904) (Court had jurisdiction to hear plaintiff's alternative claims for rescission of a contract to convey land or for an order to convey. certain land to him, although the latter claim did not satisfy the requisite jurisdictional amount); Ridder Bros., Inc. v. Blethen, 142 F.2d 395, 399 (9th Cir. 1944) ("[I]f the federal jurisdiction is fixed as to any part of the action, it is fixed as to the whole thereof.").

186 Peavey v. Reed Co., 41 F. Supp. 351, 353 (E.D.N.Y. 1941) (specific performance of a contract for release of a tort claim); Comment, Federal Jurisdiction: Amount in Controversy in Suits for Nonmonetary Remedies, 46 CALIF. L. REv. 601, 608 (1958).

187 In an action to secure injunctive relief, the value of the right or interest sought to be protected determines the amount in controversy. See 1 J. MOORE, supra note 180 , at $\mathbb{f} 0.96$, at $866-72$ (injunctions against private acts). In Campbell Soup Co. v. Diehm, 111 F. Supp. 211 (E.D. Pa. 1952), the plaintiffs sought to enjoin certain farmers from breaching their contracts to sell crops to the plaintiffs. Although the court recognized that the actual value of the property in question ordinarily determines the amount in controversy in an action for specific performance of a sales contract, it rejected the defendants' contention that such a test denied it jurisdiction over the plaintiffs' action. Instead, it found that the plaintiffs sought to protect "a plan of doing business and a vast system of manufacture" threatened with irreparable damage by the defendants' breach of their contract. Id. at 214 . The court's reasoning suggests that in the proposed litigation to enjoin contractor discrimination in violation of the Order the amount in controversy should be measured by the value of the interest to be protected-the continued operation of the construction project. 
operations because of a contractor's failure to fulfill his contractual obligations, a university could easily prove potential damages from contractor noncompliance in excess of 10,000 dollars. Thus the proposed litigation would satisfy the jurisdictional amount even in the absence of a prayer for a declaration that the entire contract was invalid.

\section{(b) Federal Question ${ }^{188}$}

\section{(1) Characterization of the Complaint}

To warrant jurisdiction, the federal question in the case must arise on the face of a properly pleaded complaint rather than by way of an anticipated defense or irrelevant background. ${ }^{189}$ This requirement, the so-called well-pleaded complaint rule, ${ }^{100}$ is satisfied if the university seeks specific performance and affirmative relief, because federal elements in such claims do not fall in the categories of anticipated defenses or explanatory matter. The court might decide, however, that the analogies drawn from the interpretation of "discrimination" and "affirmative action" under title VII do not provide adequate standards by which to determine what the equitable relief should be, and, upon appropriate motion, dismiss the prayer for specific performance as failing to state a claim on which relief can be granted. ${ }^{191}$ The university would then be left with the decidedly more difficult task of grounding federal question jurisdiction in a prayer for a declaratory judgment.

The problem with the latter approach lies in the application of the well-pleaded complaint rule to declaratory judgments. On the one hand, it is possible to judge the complaint on its own merits; if the complaint as stated relies on federal law, jurisdiction exists. The other possibility is to use an historical test, holding that the action can be entertained in federal court only if the underlying coercive action might have been so brought. This test was announced in Skelly Oil Co. v. Phillips Petroleum Co., ${ }^{192}$ in which Justice Frankfurter reasoned that testing federal question jurisdiction solely on the face of the complaint would destroy the limited procedural purpose of the Declaratory Judgment Act and permit "artful pleading" to gain jurisdiction for a suit which could not otherwise be heard in federal court.

18828 U.S.C. $\$ 1331$ (1964).

189 Gully v. First Nat'l Bank, 299 U.S. 109, 112-13 (1936).

190 See Mishkin, The Federal "Question" in the District Courts, 53 Colum. L. REv. 157, 176 (1953).

191 FED. R. CIV. P. 12(b) (6).

192339 U.S. 667 (1950). 
Application of the Skelly Oil test raises a significant obstacle to the proposed litigation. Assuming that no specific relief was available, a court could find that the university's federal claim arises only as a defense to the contractor's potential state action for damages. The rule of Louisville and Nashville Railroad Co. v. Mottley ${ }^{193}$ would then apply, denying federal jurisdiction.

Although much criticized by scholars, ${ }^{194}$ the Skelly Oil test has never been rejected by the Supreme Court. Thus, disregarding the prayer for specific performance, the pleadings would probably not be judged on their face for purposes of determining federal question jurisdiction and the courts would lack jurisdiction over the university's action for a declaratory judgment.

\section{(2) Incorporation.}

The issue remains whether the complaint, even if judged on its face rather than by the underlying coercive action, actually raises a federal question. The action is fundamentally contractual. The university is not suing directly on a federal right, but on federal standards as incorporated into an agreement between private parties. The question is whether that incorporation raises a federal question for jurisdictional purposes.

The incorporation issue is another unsettled area of the law. Cases are often distinguished on the basis of whether the federal law is merely used as a standard for essentially state or contractual duties or also operates independently. The federal interest in having the suit adjudicated in federal court appears most significant when "the same issues involving the same course of conduct could have been litigated in a federal cause of action had the parties or the form of the lawsuit only been different." 195 This analysis supports federal

193211 U.S. 149 (1908).

104 Professor Mishkin has suggested that Skelly Oil is based on a misreading of the Court's earlier admonition that the "operation of the Declaratory Judgment Act is procedural only," Aetna Life Ins. Co. v. Haworth, 300 U.S. 227, 240 (1937); that the admonition was anchored in a fear that the Act might be unconstitutional for granting jurisdiction over cases not yet ripened into justiciable controversies under U.S. CoNST. art. III, \$2; and that the applicability of the Court's reasoning in Skelly Oil to federal question jurisdiction, where the issue is statutory rather than constitutional, is thus questionable. Mishkin, supra note 190 , at $178 \mathrm{n} .99$; see id. 182-84 (Skelly Oil can be construed as limited to cases not "directly" founded upon federal law). Several commentators have also suggested rejecting the test announced in Skelly Oil and, when the issue is the existence of a federal question, analyzing the pleadings in a declaratory action on their face. Id. 176-84; see Cohen, The Broken Compass: The Requirement that a Case Arise "Directly" under Federal Law, 115 U. PA. L. REv. 890, 894-95 n.26 (1967); Currie, The Federal Courts and the American Law Institute, Part II, 36 U. CHI. L. REv. 268, 269-71 (1969). The American. Law Institute has offered similar suggestions in its proposed revision of the Judicial Code. Ali Study of the Division of Jurisdiction Between State aNd Federal Courts 24, 169-72 (1968).

195 Greene, Hybrid State Law in the Federal Courts, 83 Harv. L. Rev. 289, 301 (1969). 
jurisdiction for the university's case because the identical issues might arise in a Government suit against the contractor. ${ }^{196}$ Although federal jurisdiction in such cases might be found objectionable for opening the federal courts to numerous actions based on incorporation of federal standards into private contracts, ${ }^{197}$ the incorporation of the provisions in question results from federal law, not private party agreement. Moreover, the federal requirement of incorporation emphasizes the strong federal interest in having such claims heard in a federal court where they are more likely to receive a sympathetic hearing and consistent interpretation.

Judicial precedent exists for according federal jurisdiction to the proposed litigation, assuming the complaint is analyzed on its face. In Smith v. Kansas City Title \& Trust Co., ${ }^{198}$ the Supreme Court sustained federal jurisdiction over a stockholder's suit to enjoin directors from investing in federal farm loan bonds on the ground that state law prohibited investment in unauthorized issues and that the bond's authorization was unconstitutional. Professors Hart and Wechsler have suggested that the case might support the larger proposition that

an action arises under federal law, for the purposes of statutory grants of original district court jurisdiction, if in order for the plaintiff to secure the relief sought he will be obliged to establish both the correctness and the applicability to his case of a proposition of federal law-whether that proposition is independently applicable or becomes so only by reference from state law. ${ }^{198}$

In short, if the university can bypass the Skelly Oil test, federal question jurisdiction for the declaratory judgment action should be available in the district courts.

\section{b. Administrative Preemption}

Discussion of administrative preemption of the controversy requires a preliminary distinction. If a university bargains for specific actions not required of the contractor by rules and regulations promulgated under Executive Order 11246, the university's suit for nonperformance will not raise the question of administrative preemption; the federal agencies cannot have exclusive jurisdiction over what is

196 See Exec. Order No. 11,246, $\$ 209$ (a) (1)-(4), 3 C.F.R. 406 (1970), 42

U.S.C. \$2000e (Supp. V, 1970).

197 See Cohen, supra note 194, at 910.

198255 U.S. 180 (1921).

199 HART \& WECHSLER, supra note 172, at 769. 
beyond their command. For example, if the contractor promises to recruit its labor force from specified minority group referral organizations, but neither the agency nor the OFCC rules require him to do so, ${ }^{200}$ the university's suit challenging the contractor's performance would not be dismissed on the ground of administrative preemption, although it might be dismissed for failure to present a federal question. The problem of administrative preemption arises only when the contractor's obligations are not viewed as specially "bargained for" by the university, as when the contract merely contains the language required by Executive Order 11246 . The Tufts contract, and most contracts heretofore negotiated under the Order, fit into this category.

A strong argument can be made that a university should be denied the power to enforce the requirements of Executive Order 11246 as copied into this latter variety of contract. The Order appears to delegate exclusive power over administration and enforcement to the Government; the administering agencies are given primary responsibility for obtaining compliance with rules propounded by the Secretary of Labor ${ }^{201}$ and are directed to attempt to impose sanctions on the contractor only after attempting to obtain compliance through "conference, conciliation, mediation, or persuasion." 202 Thus the university's attempt to enforce the Order by judicial action might be considered improper interference with the administrative compliance scheme. The university's role as grantee of federal funds under the Order and regulations is at best subsidiary. The regulations plainly direct the university to "assist the administering agency in the discharge of the agency's primary responsibility for securing compliance." ${ }^{203}$

The vesting of this primary authority for enforcing Executive Order 11246 in government officials does not, however, entirely foreclose adjudication of the university's claim, for the proposed litigation need not necessarily be characterized as an action to enforce the Order. Rather, the university's complaint could emphasize that the provisions of the Order were merely incorporated into a private contract. Recourse to administrative regulations might then be required to interpret the intention of the parties, but would not necessarily preclude characterization of the action as essentially contractual.

The case law on this issue is sparse. The Supreme Judicial Court of Massachusetts accepted Tufts' characterization of such an action as contractual :

200 E.g., Harvard contract discussed at text accompanying notes 263-74 infra.

201 Exec. Order No. 11,246, §205, 3 C.F.R. $404-05$ (1970), 42 U.S.C. $\$ 2000 \mathrm{e}$ (Supp. V, 1970). 1970).

202 Id. $\S \S 205,209$ (b), 3 C.F.R. 405, 406 (1970), 42 U.S.C. $\$ 2000 \mathrm{e}$ (Supp. V, 20341 C.F.R. $\$ 60-1.4$ (b) (7) (1970) (emphasis added). 
In the instant case the University does not seek to enforce the terms of the Executive Order but seeks to enforce the provisions of its contract with the defendant. The fact that a specific provision in the contract is covered by a regulation of a Federal agency regarding the enforcement of that regulation does not deprive the University of the right to enforce the contractual obligations. ${ }^{204}$

But other courts have denied standing, on grounds of administrative preemption, to even the actual beneficiaries of the Order, minority group workers alleging discrimination. In Farkas v. Texas Instrument, Inc., ${ }^{205}$ the Fifth Circuit held that a worker's claim of employer discrimination violating the Executive Order did not state a claim upon which relief could be granted. The court relied heavily on the history and enforcement of the Order, finding an intent not to allow judicial actions initiated by private parties, even after a plaintiff had exhausted all administrative remedies.

The issue of administrative preemption, then, is far from resolved. Characterization of the litigation as contractual and the resolution of two parties' obligations under a document they negotiated may provide a basis for judicial cognizance of the action. But the delegation of enforcement powers to the administering agency provides a formidable barrier to judicial relief.

\section{c. Primary Jurisdiction}

Even if the Order does not preclude university enforcement of its provisions copied into the construction contract, the doctrine of primary jurisdiction may transfer the initial determination of compliance from the court to the agency. Unlike administrative preemption, primary jurisdiction does not exclude judicial contemplation of the action. The doctrine merely requires, whenever a court finds that an agency has exclusive authority to make certain determinations deemed relevant to the controversy, that judicial action be held in abeyance until the agency's determinations are completed. ${ }^{206}$

Professor Jaffe ${ }^{207}$ has suggested three reasons for the operation of the doctrine. Uniformity of decision is of first importance. The efficient and effective administration of the vast number of contracts subject to the Executive Order obviously requires uniformity of interpretation. The other two reasons, the necessity of investigation and

204 Trustees of Tufts College v. Volpe Constr. Co., M-7379 (Mass. Sup. Jud. Ct., Dec. 8, 1970).

205375 F.2d 629, 632-33 (5th Cir.), cert. denied, 389 U.S. 977 (1967) ; see Farmer v. Philadelphia Elec. Co., 329 F.2d 3, 8-10 (3d Cir. 1964) (dictum); cf. Gnotta v. United States, 415 F.2d 1271 (8th Cir. 1969).

206 See Texas \& Pac. Ry. v. Abilene Cotton Oil Co., 204 U.S. 426 (1907).

207 L. Jaffe, Judicial Contror of Administrative Action 121-34 (1965). 
evaluation of complex and technical materials and the need for the employment of expertise in the area, are less than compelling in the case of university-contractor litigation. As argued above, ${ }^{208}$ judicial experience with questions of racial discrimination and its remedies under title VII provides adequate standards for adjudication of contractor compliance without expert analysis of complex data.

Thus a court taking jurisdiction over the university's action might defer to the Secretary of Labor or the administering agency for a definition of compliance. Invocation of primary jurisdiction would be unusual absent an established administrative proceeding for determination of the issues in the university-contractor situation, but it might be necessary for the court to ask the agency to make a presentation before the court. ${ }^{209}$ In any event, a finding of primary jurisdiction would undercut the university's purpose for pursuing judicial action-circumvention of the slow and inadequate administrative process.

\section{d. Joinder of Parties}

\section{(i) Government Agency}

A significant argument can be made that the agency granting money to the university should be joined under rule 19 of the Federal Rules of Civil Procedure as a party to the university-contractor litigation. The agency's ability to institute subsequent proceedings might well make it "so situated that the disposition of the action in [its] absence may . . . leave [one] of the persons already parties subject to a substantial risk of incurring double, multiple, or otherwise inconsistent obligations by reason of [its] claimed interest." 210

If the agency is so characterized, rule 19 provides that it will be joined unless the joinder would deprive the court of jurisdiction over the subject matter. In the university-contractor litigation jurisdiction would not be defeated unless the agency refused to join and the court endeavored to make it a defendant rather than an involuntary plaintiff. ${ }^{211}$ Such judicial characterization of the agency position would again raise the spectre of sovereign immunity. ${ }^{212}$

208 Text accompanying notes $107-30$ supra.

209 JAFFE, supra note 207, at 1038.

210 FED. R. CIV. P. 19(a) (2) (ii), State joinder rules may well be less demanding. In the Tufts litigation, for example, the Supreme Judicial Court of Massachusetts held that even assuming that the Secretary of Labor was the enforcing party as far as Executive Order 11246 was concerned, he was not a necessary party under state law. The court emphasized that the university was seeking to enforce its contract rather than the Order, and reasoned that all persons or groups who might conceivably be affected by the outcome of the contractual litigation did not need to be made parties to the suit. Trustees of Tufts College v. Volpe Constr. Co., M-7379 (Mass. Sup. Jud. Ct., Dec. 8, 1970).

211 FED. R. Civ. P. 19(a) (2) (ii).

212 See note 172 supra. 
Characterization of the agency as a defendant appears unlikely, however, because of the agency's general alignment with the interests of the university. But even if the agency were so characterized, the probable consequence would be dismissal of the agency from the action rather than dismissal of the entire suit for nonjoinder. All four considerations specified by rule 19 (b) to be weighed in deciding whether the entire action should be dismissed support retention of the suit. For example, judgment rendered in the absence of the agency would hardly be prejudicial to the parties. The agency's failure to join would imply lack of interest in the proceedings and could consequently suggest the improbability of subsequent agency action against the contractor. Similarly, given the university's lack of standing in administrative proceedings and its inability to sue the agency, the university's situation clearly fits the rule's policy that a plaintiff should not be left without an adequate remedy because of dismissal for nonjoinder.

Hence, application of the joinder provisions to the agency should benefit rather than deter the university's proposed litigation. Rule 19 may bring the agency into the litigation, perhaps adding support for the university's position and providing the means for presentation of any finding required by primary jurisdiction.

\section{(ii) Unions}

Even more persuasively, rule 19 would require joinder of any union locals involved in preferential hiring hall agreements with the contractor. Without joinder the court would be unable to reach the contractor's contractual relationship with the unions, and would be forced to choose between two courses of action, either of which would necessitate recourse to the joinder rules. If the court found for the university but refused to require minority group hiring because unwilling to interfere with the contractor's union agreements, it would be withholding complete relief solely because of the absence of the unions. $^{213}$ If, on the other hand, the court granted the university's prayer for specific performance of the contractor's hiring duty as defined by title VII analogies, it might leave the contractor subject to inconsistent obligations. ${ }^{214}$ Hence, the union locals satisfy the rule 19 standards for persons to be joined if feasible. Joinder of the unions would be less likely to precipitate dismissal of the action than joinder of the government agency. The unions' presence would not affect the court's subject matter jurisdiction and service of process on the locals should be easily effectuated. 


\section{Conclusion}

The judicial system fails as a productive source for achieving the university's aims. Ripeness and sovereign immunity would defeat jurisdiction in an action against the government agency. Administrative preemption and the Skelly Oil doctrine might well bar a suit against the contractor. Moreover, the actions contemplated could not deal with the university's basic problems. Vindication of the university's actions in a suit against the agency would neither appease the students nor result in the hiring of more minority group workers. A favorable decision against the contractor probably could not be reached before the completion of the construction. The litigation would then at best serve as precedent for subsequent confrontations. In short, if judicial action were the only available approach, the university's role in promoting minority group employment in the construction industry would be insignificant.

\section{The Precontractual Approach}

The previous section has demonstrated that the limitations on administrative and judicial action prevent a university from effectively promoting minority group employment on its own construction projects, or in the industry as a whole, if the university is limited to enforcing an undefined equal employment opportunity clause in its general contract. A more promising approach would seem to be the inclusion of well-defined obligations in the construction contract prior to its award. Such clauses would represent part of the university's specifically bargained-for consideration rather than the mere incorporation of the vague, difficult administrative specifications of the Order, and enforcement of the clauses should clearly be available at least in the state courts. ${ }^{215}$ To determine what provisions to include in its contract, the university should examine recent executive promulgations relating to specific geographical areas. Such rulings provide the most sophisticated administrative analogue to a private precontractual approach.

\section{A. Recent Trends in the Scope of the Contractor's Duty Under Executive Order 11246}

1. The Philadelphia Plan ${ }^{216}$

On June $27,1969,{ }^{217}$ finding especially severe underemployment 215 Text accompanying note 200 supra. 2162 CCH Emp. Prac. Guide \16,175 (June 27, 1969) [hereinafter cited as June 27, 1969 Order].

217 A second order was issued on September 23, 1969. 2 CCH Exr. PrAc. GuIDE $\llbracket 16,176$ (Sept. 23, 1969) [hereinafter cited as September 23, 1969 Order]. The Plan 
of minority group workers in seven skilled construction trades ${ }^{218}$ in the Philadelphia area, ${ }^{219}$ the Department of Labor produced the Philadelphia Plan to elucidate the "affirmative action" obligation of Executive Order 11246. The Plan's stated policy was that

In order to promote the full realization of equal employment opportunity on Federally-assisted projects, it is the policy of the Office of Federal Contract Compliance that no contracts or subcontracts shall be awarded for Federal and Federally-assisted construction in the Philadelphia area on projects whose cost exceeds $\$ 500,000$ unless the bidder submits an acceptable affirmative action program which shall include specific goals of minority manpower utilization, meeting the standards included in the invitation or other solicitation for bids, in trades utilizing [certain] classifications of employees .... ${ }^{220}$

The Plan is based on a comprehensive study by OFCC, setting specific quantitative minority manpower goals for each of the specified trades over a period of four years. The targets range from an average of four to nine percent minority employment in the first year to nineteen to twenty-four percent in the fourth year. ${ }^{221}$ To be eligible for a contract, the bidder must set specific goals within this range for minority manpower utilization in his affirmative action program. ${ }^{222}$ If the contractor meets the percentage goals according to schedule, he is presumed to be in compliance with Executive Order 11246.

became effective on September 29, 1969. An earlier plan had been put into effect on November 30, 1967. June 27,1969 Order. It required contractors to state numerical goals in such a way as to serve as part of the basis for determining the lowest responsible bidder, but it was suspended because of an opinion by the Comptroller General that it violated the principles of competitive bidding. But see Weiner v. Cuyahoga Community College Dist., 19 Ohio St. 2d 35, 249 N.E.2d 907 (1969), cert. devied, 396 U.S. 1004 (1970) ("Cleveland Plan" based on similar principles constitutional and a proper action under title VII). The Comptroller General now opposes the revised Plan on the ground that it violates title VII. Philadelphia Plan Viezed as Illegal by Comptroller General, 1 CCH Exr. PRAc. Gume If 5082 (Aug. 5, 1969); note 225 infra.

218 The trades were subsequently reduced to six: ironworkers, plumbers and pipefitters, steamfitters, sheet metal workers, electrical workers, and elevator construction workers. September 23, 1969 Order $\$ 2$.

219 The Department of Labor is considering the extension of the "Philadelphia Plan" concept to 18 cities unless they devise their own plans for ending job discrimination in the construction industry: N.Y. Times, Feb. 10, 1970, at 30, col. 5. Chicago and Pittsburgh were cited as cities which have devised such acceptable "home town solutions." Text accompanying note 274 infra. Other cities have subsequently negotiated similar plans. Note 281 infra.

220 June 27,1969 Order $\$ 3$.

221 September 23, 1969 Order § 4.

222 If the contractor agrees to participate in a multi-employer areawide program approved by OFCC, he is not subject to the minority manpower goals requirement. June 27, 1969 Order \& 5; see note 219 supra. 
The Plan gives content to the rhetoric of OFCC regulations ${ }^{223}$ by establishing a standard by which compliance can be measured. The specific standard benefits the enforcement agency by ostensibly ensuring immediate entrance of minority group workers into the construction industry, and by providing a readily administrable measure of compliance with the "affirmative action" obligation. ${ }^{224}$ The standard provides the contractor with a concrete formula for compliance. Despite these advantages, the Philadelphia Plan raises substantial legal questions, particularly concerning the legality of its numerical goals, a point vigorously debated by the Comptroller General ${ }^{225}$ and the Attorney General. ${ }^{226}$ The Plan raised strong opposition from both the contractors and unions. ${ }^{227}$ The Philadelphia Plan must be thoroughly examined to judge whether it requires illegal quota hiring before its principles are proposed for inclusion in a university construction contract.

\section{The Legality of Minority Group Employment Quotas}

\section{a. The Impact of Title VII}

Although title VII does not wholly preempt executive power to implement a policy of nondiscriminatory employment, ${ }^{228}$ it does limit that power. The Executive may not impose requirements that in themselves require a contractor to violate the nondiscrimination provisions of the Act.

223 For a discussion of those regulations as made applicable to postcontractual compliance efforts, see text accompanying notes 102-06 supra.

224 Labor Dep't Issues Policy Statement Describing Its Role in Civil Disputes Affecting Construction Industry, $1 \mathrm{CCH}$ EMP. PRAC. GUIDE If 8118 (Oct. 9, 1969); Fletcher, Implications of Philadelphia Plan for Minority Contractors, 1 CCH EMP. PRAC. Guide $\{8096$ (Aug. 25, 1969).

225 The Comptroller General argued that the Plan requires quota hiring, and subsequently refused to authorize expenditures under it. Philadelphia Plan Vieved as Illegal by Comptroller General, 1 CCH Emp. Prac. GuIDE $\{5082$ (Aug. 5, 1969).

226 The Attorney General argued that the Plan does not require quota hiring. Attorney General Decides Philadelphia Plan Is Legal, 1 CCH EMp. PRAC. Guide II 5083 (Sept. 22, 1969). In Congress an amendment was defeated which would have given the Comptroller General explicit authority to cut off federal funds to those programs he felt were illegal. The amendment was commonly referred to as the "Philadelphia Plan rider." 115 Cong. REc. S 17624-35 (daily ed. Dec. 22. 1969). Although the Senate first passed the amendment, id. S 17131, S 17151, S 17157 (daily ed. Dec. 18, 1969), the House defeated it, id. H 13983-89 (daily ed. Dec. 23, 1969), and the Senate also reversed itself. Id. S 17623-36 (daily ed. Dec. 22, 1969). Recognizing the apparent congressional desire to implement the Plan, the Comptroller General has dropped his previously announced plans to refuse to pay contractors complying with its terms. Comment, The Philadelphia Plan and Strict Racial Quotas on Federal Contracts, 17 U.C.L.A.L. REv. 817, 824 (1970).

227 See, e.g., Contractors Ass'n v. Shultz, 311 F. Supp. 1002 (E.D. Pa. 1970). 228 See note 107 supra. 
(i) Section 703(j)

Nothing contained in this subchapter shall be interpreted to require any employer, employment agency, labor organization, or joint labor-management committee subject to this subchapter to grant preferential treatment to any individual or to any group because of the race, color, religion, sex, or national origin of such individual or group on account of an imbalance which may exist with respect to the total number or percentage of persons of any race, color, religion, sex, or national origin employed by any employer, referred or classified for employment by any employment agency or labor organization, admitted to membership or classified by any labor organization, or admitted to, or employed in, any apprenticeship or other training program, in comparison with the total number or percentage of persons of such race, color, religion, sex, or national origin in any community, State, section, or other area, or in the available work force in any community, State, section, or other area. ${ }^{229}$

The proviso raises the issue whether an executive requirement of "preferential treatment" or quota hiring of minority group workers would itself violate title VII. On its face the section does not apply to substantive obligations outside title VII's legislative scheme. Rather, the proviso simply states that "[n]othing contained in this subchapter shall be interpreted to require . . . preferential treatment." Arguably, therefore, the Executive may, consistent with title VII, establish higher substantive standards for achieving equal employment opportunity. ${ }^{230}$

The legislative history clarifies the limited purpose of the proviso. Southern Senators argued that the proposed bill would require preferential treatment of minority group workers, quota hiring, and racial balancing. ${ }^{231}$ The Department of Justice ${ }^{232}$ and Senators Clark and Case, bipartisan captains of the bill, ${ }^{233}$ answered these objections in separate interpretative memoranda, arguing that the Act did not require such practices. ${ }^{234}$ The proviso was then inserted to prevent an inter-

22942 U.S.C. $\$ 2000 \mathrm{e}-2(\mathrm{j})(1964)$.

230 See Note, supra note 1, at 599-600.

231 See Berg, Equal Employment Opportunity Under the Civil Rights Act of 1964, 31 BRoOKLYN I. Rev. 62, 76 (1964) ("Perhaps no charge was made more frequently by the opponents of Title VII, both in and out of Congress, than that the title would require or authorize the imposition of racial quotas upon employers and labor organizations."); Cooper \& Sobol, supra note 109, at 1613.

232110 CoNG. REC. 7213 (1964).

233 Id. 7217.

234 There is no requirement in title VII that an employer maintain a racial balance in his work force. On the contrary, any deliberate attempt to maintain a racial balance, whatever such a balance may be, would involve a violation of title VII because maintaining such a balance would require the employer to hire or to refuse to hire on the basis of race. It must be emphasized that discrimination is prohibited as to any individual. While the pres- 
pretation making maintenance of a racially imbalanced work force illegal per se. ${ }^{235}$ Section $703(j)$, therefore, only establishes that quota hiring is not required by title VII. It does not determine whether quota hiring is actually illegal. ${ }^{236}$

\section{(ii) The General Nondiscrimination Provisions}

Affirming the purpose of the Act, both legislative history and judicial dicta have deemed quota hiring invalid under title VII. ${ }^{237}$ For example, on the date the Act was signed, Senator Humphrey issued "A Concise Explanation of the Civil Rights Act of 1964":

The title does not provide that any preferential treatment in employment shall be given to Negroes or to any other persons or groups. It does not provide that any quota systems may be established to maintain racial balance in employment. In fact, the title prohibits preferential treatment for any particular group. ${ }^{238}$

Similarly, in Weiner v. Cuyahoga Community College District, ${ }^{239}$ although upholding one aspect of a plan similar to the Philadelphia Plan, the Ohio Supreme Court stated: "The establishment of a quota of

ence or absence of other members of the same minority group in the work force may be a relevant factor in determining whether in a given case a decision to hire or to refuse to hire was based on race, color, etc., it is only one factor, and the question in each case would be whether that individual was discriminated against.

Id. 7213 .

235 Cooper \& Sobol, supra note 109, at 1613-14.

236 See generally note 249 infra.

237 The imposition of racial employment quotas either by the government or private parties arguably would violate the equal protection clause. Cf. Shelley v. Kraemer, 334 U.S. 1 (1948); Hellerstein, The Benign Quota, Equal Protection, and "the Rule in Shelley's Case," 17 RutGers I. REv. 531 (1963) ; Shubert, State Action and the Private University, 24 RUTGERs L. REv. 323 (1970). Although the constitutionality of preferential treatment in general is unsettled, it has been argued that the courts should apply a permissive standard of review. See generally Developments in the Law-Equal Protection, 82 HARv. L. REv. 1065, 1104-20 (1969). One commentator has argued that governmental imposition of racial quotas is not only constitutionally permissible but constitutionally required. Comment, supra note 226 , at 829-35; cf. Comment, The Constitutionality of "Affirmative Action" to Integrate the Construction Trades: The Philadelphia Plan, 43 TeMple L.Q. 329 (1970).

238110 Cong. REc. 15,866 (1964). Other portions of the legislative history support his statement. Senator Clark, the floor manager for the majority, stated:

There is no provision . . . that requires or authorizes any Federal agency or Federal court to require preferential treatment for any . . . group for the purpose of achieving racial balance. . . The same is true of labor organizations. . . [A]ny deliberate attempt to maintain a given balance would almost certainly run afoul of title VII. . . . What title VII seeks to accomplish . . . is equal treatment for all.

Id. 7207 ; see id. 7217 (Clark-Case interpretative memorandum).

23919 Ohio St. 2d 35, 249 N.E.2d 907 (1969), cert. denied, 396 U.S. 1004 (1970). 
employment of any particular minority would . . . be discriminatory in violation of the Civil Rights Act of 1964." 240

Even though title VII has been interpreted to forbid all quotas, a further question is whether title VII requires "colorblind" employment practices, as the Comptroller General argued in his broadside attack upon the Philadelphia Plan. ${ }^{241}$ The language of section 703(a) seems to lead reasonably to such a conclusion, for it provides that an employer may not "fail or refuse to hire . . . any individual, or otherwise .. . discriminate against any individual with respect to . . . terms . . . of employment, because of such individual's race . . . ." 242 But if title VII were so interpreted, the Philadelphia Plan could not stand despite its safeguards because it makes race a factor in hiring practices and procedures. ${ }^{243}$ To interpret title VII to require completely colorblind hiring practices, however, would not only make the title internally inconsistent but might also render it unconstitutional.

Title VII prohibits not only overt racial discrimination but also practices which, although neutral on their face, adversely affect minority group workers without the justification of business necessity. ${ }^{244}$ An employer must consequently be "racially conscious" in order to comply with the statute. ${ }^{245}$ It would be anomalous to require eradication of discriminatory employment practices in one sentence and deny effective implementation of this obligation in the next. Moreover, because of the federal government's involvement in federal and federally

240 Id. at 39, 249 N.E.2d at 910 . Those courts which have directly considered racial quotas in other areas have found them unlawful. See Hughes v. Superior Court, 32 Cal. 2d 850, 198 P.2d 885, aff'd, 339 U.S. 460 (1950) (injunction issued to restrain picketers from attempting to induce store owners to employ workers in proportion to racial origins of customers upheld because quotas violated state policy); Developments in the Law-Equal Protection, supra note 237, at 1118.

241

Whether the provisions of the Plan requiring a bidder to commit himself to hire-or make every good faith effort to hire-at least the minimum number of minority group employees specified in the ranges established for the designated trades is, in fact, a "Quota" System (and therefore admittedly contrary to the Civil Rights Act) or is a "Goal" System, is in our view largely a matter of semantics, and tends to divert attention from the end result of the Plan-that contractors commit themselves to making race or national origin a factor for consideration in obtaining their employees.

We view the imposition of such a requirement on employers engaged in federal or federally assisted construction to be in conflict with the intent as well as the letter of the above provisions of the Act which make it an unlawful employment practice to use race or national origin as a basis for employment.

Philadelphia Plan Viezed as Illegal by Comptroller General, 1 CCH EMP. PRAC. GUIDE Tा 5082, at 3787 (Aug. 5, 1969). 24242 U.S.C. $\$ 2000 \mathrm{e}-2$ (a) (1964). at 333 .

243 See Comment, The Constitutionality of "Affirnative Action," supra note 237,

244 Text accompanying notes $108-22$ supra.

245 Text accompanying notes $129-30$ supra. 
assisted construction, ${ }^{246}$ acquiescence in the perpetuation of discrimination through "neutral" employment practices by pursuing a colorblind policy would be unconstitutional. ${ }^{247}$ The sounder interpretation, more consonant with title VII's broad purpose to end employment discrimination, ${ }^{248}$ is that although an employer may perhaps not hire for the sake of a quota solely on the basis of race without regard to individual qualifications, he often must take the racial consequences of his employment practices into account. ${ }^{249}$

\section{b. Implications of Title VII for the Philadelphia Plan}

In the Philadelphia Plan ${ }^{250}$ the Government devised two safeguards against quota hiring. First, it commissioned a detailed study of the Philadelphia area to fix ranges of minority employment which a nondiscriminatory affirmative action program would produce. Second, the obligation to meet the Plan's goals is not absolute: "In the event of failure to meet the goals, the contractor shall be given an opportunity to demonstrate that he made every good faith effort to meet his commitment." 251 And, in "any proceeding in which such good

246 Comment, The Constitutionality of "Affirmative Action," supra note 237, at 333-35; Comment, supra note 226, at 832-35.

247 Sources cited note 246 supra. In Norwalk CORE v. Norwalk Redev. Agency, 395 F.2d 920, 931-32 (2d Cir. 1968) (footnotes omitted), the court stated:

What we have said may require classification by race. That is something which the Constitution usually forbids, not because it is inevitably an impermissible classification, but because it is one which ustally, to our national shame, has been drawn for the purpose of maintaining racial inequality. Where it is drawn for the purpose of achieving equality it will be allowed, and to the extent it is necessary to avoid unequal treatment by race, it will be required.

248 See Note, supra note 55 , at 33.

249 Phrasing the issue in terms of preferential treatment makes this distinction more difficult to articulate. Suppose a contractor has a hiring hall arrangement with a union discriminating against minority group workers in referrals. If the contractor does not broaden his recruitment base to include referrals from the minority community, he may have violated both title VII and the Executive Order. See text accompanying notes 107-30 supra. But if he hires a minority group worker when an equally or more qualified white is available in the hall, he may be subject to a charge of preferential treatment. The issue may be semantically unresolvable, but because white workers as a group are not entitled to continued preference in hiring, their employment opportunities as a group must arguably be curtailed to eradicate discrimination against minority group workers. Cf. Blumrosen, supra note 109, at 490. Section $703(j)$ itself recognizes this point by seemingly not applying where the contractor is under an obligation to eradicate the effects of prior discrimination. Section $703(j)$ merely states that the Act is not to require preferential treatment "on account of" racial imbalance. See Berg, supra note 231, at 76-78; Blumrosen, supra note 109, at 492-94; Gould, Black Power in the Unions, 79 YALE L.J. 46, 81 n.155 (1969).

Of course, all attempts at distinction may be fruitless and quota hiring may not only be valid under title VII but also constitutionally required to eradicate discrimination. See note 237 supra. The discussion in the text assumes the invalidity of quotas because of the obvious risks a university would encounter if it challenged the existing judicial and legislative precedents by including quotas in its contract.

250 June 27, 1969 Order.

251 Id. \& 8a. 
faith performance is in issue, the contractor's entire compliance posture shall be reviewed and evaluated in the process of considering the imposition of sanctions." 252 To obviate any charge that good faith requires reverse discrimination, the Plan explicitly states that the contractor's obligations are "not intended and shall not be used to discriminate against any qualified applicant or employee." 253

Yet the Philadelphia Plan might still be invalid if it results in de facto quotas. Contractors may find it difficult to produce evidence of "good faith" compliance efforts without using a quota system to avoid the presumption of noncompliance. ${ }^{254}$ But accurate goals and a specific definition of "good faith" can reduce the danger of a contractor's reliance upon a de facto quota.

\section{(i) The Calculation of Goals}

To avoid the difficulty of fixing percentages that would require quotas or else be meaningless, the percentages should be calculated to reflect the availability of minority group manpower in the existing labor pool. The Philadelphia Plan listed several factors in the calculation. ${ }^{255}$ First, an accurate analysis must at least take into account three categories of minority group workers to be drawn into the labor pool: journeymen skilled in a trade, partially trained workers willing and able to move into the construction crafts with a modicum of upgrading, and untrained workers willing to be trained in a construction trade. ${ }^{256}$ Second, the analysis must take into account the location of projected construction in relation to housing patterns and available transportation. ${ }^{257}$ Third, the analysis must consider the extent of past and present discrimination in apprenticeship programs and union locals, and at construction sites. Minority group members may be

$252 I d$.

${ }^{253} I d . \S 6 \mathrm{~b}(2)$.

254 See Winter, Improving the Economic Status of Negroes Throngh Laws Against Discrimination: A Reply to Professor Sovern, 34 U. CHI. L. REv. S17, 83435 (1967). Interestingly, Professor Winter's argument was primarily directed toward title VII. Cf. Berg, supra note 231, at 76-78.

255 June 27, 1969 Order $\$ 6 c$, listed four critical factors:

(1) The current extent of minority group participation in the trade.

(2) The availability of minority group persons for employment in such trade.

(3) The need for training programs in the area and/or the need to assure

demand for those in or from existing training programs.

(4) The impact of the program upon the existing labor force.

258 Although determining the number of fully qualified journeymen in minority groups may involve a simple head count, the determination of prospective craftsmen entails subtle calculations. Cf. M. Zymelman, Criteria for Targets for Job Creation and Job Upgrading for the Nonwhite Urban Ghetto Labor Force: An Analysis and Projection of Metropolitan Area Manpower Demand and Supply, Nov. 1968 (unpublished paper prepared for "The Urban Ghetto Study Program" of The Laboratory for Environmental Studies, MIT).

257 See text accompanying note 67 supra. 
reluctant to enter the skilled trades because of past discrimination; ${ }^{258}$ but intensive recruitment efforts can make them part of the available labor pool. Finally, the analysis must take into account existing training programs. The means for preparing untrained minority group workers for entry into the trades are essential. These calculations are difficult but available statistical techniques can provide reasonably accurate standards for dealing with employment problems in a particular area.

\section{(ii) Standards of Good Faith}

Standards of good faith should be objective, reasonable, and as specific as possible to obviate employer recourse to the concrete goals of quota hiring. Under the Philadelphia Plan good faith is determined by the contractor's efforts to "broaden his recruitment base" through the following activities:

(a) The OFCC Area Coordinator will maintain a list of community organizations which have agreed to assist any contractor in achieving his goal of minority manpower utilization by referring minority workers for employment in the specified trades. A contractor who has not met his goals may exhibit evidence that he has notified such community organizations of opportunities for employment with him on the project for which he submitted such goals as well as evidence of their response.

(b) Any contractor who has not met his goal may show that he has maintained a file in which he has recorded the name and address of each minority worker referred to him and specifically what action was taken with respect to each such referred worker. If such worker was not sent to the union hiring hall for referral or if such worker was not employed by the contractor, the contractor's file should document this and the reasons therefor.

(c) A contractor should promptly notify the OFCC Area Coordinator in order for him to take appropriate action whenever the union with whom the contractor has a collective bargaining agreement has not referred to the contractor a minority worker sent by the contractor or the contractor has other information that the union referral process has impeded him in his efforts to meet his goal.

(d) The contractor should be able to demonstrate that he has participated in and availed himself of training programs in the area, especially those funded by this Department referred to in Section 3(c) of this Order [Manpower Ad- 
ministration], designed to provide trained craftsmen in the specified trades. ${ }^{259}$

Aimed at recruitment and training, the primary means of increasing minority group employment in the construction trades, these standards are sufficiently specific to diminish most of the danger of quota hiring. Yet these standards reintroduce, albeit in a more sophisticated version, the procedures for compliance deemed inadequate under HUD guidelines. ${ }^{260}$ Quantitative goals, however, inform the contractor what intensive efforts he must make through the good faith procedures to attain the specified range of minority group employment.

\section{c. Conclusion}

There has been little experience under the Philadelphia Plan, but assuming the criteria enumerated above are retained, the Plan should be held consistent with title VII. Both the Attorney General and a court that has directly considered the Plan ${ }^{261}$ have found it valid despite disagreement by the Comptroller General. ${ }^{262}$ A university at the precontractual stage might desire to adopt its provisions. Private incorporation of the substance of a Philadelphia Plan, however, may result in illegality. The inherent safeguards in the administrative scheme, such as procedural due process in judging good faith and expertise in formulating goals, are absent in the case of private incorporation. These problems require further careful analysis.

\section{B. The Harvard Contract}

The factual background of the Harvard contract has been discussed. $^{263}$ This section examines the significant provisions of its final contract.

1. The Manning Tables and the Good Faith Standard

The Harvard contract provided for nineteen to twenty-three percent minority group employment in specified crafts. These goals were stated in a series of manning tables, and the contract provided that:

The Contractor assumes the affirmative duty, pursuant to Executive Order 11246, of achieving the range of minority

259 Ranges for Implementation of Philadelphia Plan, 2 CCH EMr. Prac. GuIDE II 16,176 (Sept. 23, 1969).

260 See text accompanying note 106 sipra.

261 Contractors Ass'n v. Shultz, 311 F. Supp. 1002 (E.D. Pa. 1970); cf. Weiner v. Cuyahoga Community College Dist., 19 Ohio St. $2 \mathrm{~d}$ 35, 249 N.E.2d '907 (1969), cert. denied, 396 U.S. 1004 (1970).

2621 CCH Emr. Prac. Gume $\{5082$ (Aug. 5, 1969).

263 Text accompanying notes $99-100$ supra. 
employment set forth in the attached manning table for the entire project.

A good faith standard for judging compliance followed, designed to eliminate unwarranted contractor liability and illegal quota hiring: ${ }^{264}$

The Contractor's effort and the results of his program shall be reviewed by the Contractor's E.E.O. [Equal Employment Opportunity] officer, Harvard's E.E.O. Officer and representatives of the Buildings and Grounds Department in order to determine if the Contractor has acted in good faith in the discharge of his responsibilities towards his stated policy. [Emphasis added.]

Harvard's problem was the absence of a factual basis for the goals it established. The nineteen to twenty-three percent targets ${ }^{265}$ for minority group employment in the manning tables are quite high, given the relatively low numbers of blacks and Puerto Ricans in Harvard's vicinity. ${ }^{268}$ They are, in fact, the same high goals the university rejected in earlier negotiations with black students as unreasonable and discriminatory. ${ }^{267}$ Harvard had no thorough demographic study upon which to base its percentages. Rather, Harvard accepted, with some enlargement, the figures suggested by the contractor. The university assumed that the contractor's intensive efforts would uncover sufficient minority group workers to fulfill the contractual goals, without raiding other construction projects.

The problem of setting speculative goals enters wherever there is no independently made labor study of the area, and most universities must necessarily negotiate their contracts on a subjective view of the available labor pool of minority group workers. This is unsatisfactory when contrasted with the study behind the Philadelphia Plan, for, although it may involve some speculation, the Philadelphia Plan study is supported by all the resources, experience, and expertise of the Labor Department's Division of Manpower Administration. No university or group of universities is likely to conduct as comprehensive a study; nor would their study be as acceptable to the parties.

The lack of a factual basis for the Harvard percentages again raises the question of quota hiring. And even if the contractor does not hire on the basis of quotas, he may be forced to juggle his work force on other projects, moving his minority group workers to the

264 See text accompanying notes 250-60 supra.

265 The target set for minority employment in the Public Health-Education Facilities Building was $16 \%$. This lower figure reflects the more highly technical nature of the construction.

266 See note 85 supra.

267 See text accompanying note 100 supra. 
university construction and putting white journeymen in their former jobs-all resulting in no net gain of minority group workers in the construction industry.

The increased possibility of quota hiring emphasizes the importance of a good faith standard of compliance in the Harvard contract situation. The Harvard good faith standard is more lenient than that found in the Philadelphia Plan. Under the Philadelphia Plan failure to meet percentage goals raises a presumption of noncompliance which the contractor must rebut by evidence of his good faith, but under the Harvard contract the university has the normal burden of proving the contractor's lack of good faith.

Either extreme in setting the percentage goals may produce undesirable results. The parties may be subject to the criticism that the contractual goals were actually negotiated high for publicity purposes rather than as real standards of compliance. If the university chooses relatively conservative, self-regulating goals, students may chastise it for adopting half-measures.

\section{Subcontracts}

The Contractor shall require, by use of contract clauses, that each subcontractor shall agree to the Contractor's equal employment opportunity policy.

The Contractor shall require each proposed subcontractor to submit a written affirmative action program prior to the award of the subcontract unless the requirement is waived by the Owner on subcontracts that are less than $\$ 50,000$ in value.

The Owner shall review and approve all programs and manpower tables submitted by the subcontractors.

The Harvard contract grants Harvard the right to review the manning tables and general affirmative action programs of all subcontractors. This right ensures maintenance of the general standards of the university-contractor agreement in all subsidiary agreements. Enforcing these standards is difficult, however, because the university has no direct legal relationship with the subcontractors, and thus no direct sanctions to invoke against them for noncompliance. Rather, the university would have to justify any attempt to enforce the subcontractor's promises on third party beneficiary principles.

The university could have expressly reserved the right to bring indirect pressure against the subcontractor by obligating the contractor to institute enforcement proceedings upon the university's request. Executive Order 11246 itself provides precedent for such an approach: 
a government contractor is required to "take such action with respect to any subcontract or purchase order as the contracting agency may direct as a means of enforcing such provisions including sanctions for noncompliance." 268 A provision for indemnification by the university of any damages suffered could protect the contractor in prosecuting an action on the university's behalf.

\section{Hiring}

Referral Notices

The Contractor shall direct special effort toward the recruitment of minority workers through referral agencies representing the minority community, such as the Workers Defense League, the Urban League, and the United Community Construction Workers. . . .

Job Applicants

The Contractor shall maintain records of all minority workers who apply for work directly at the job site. If the person is not hired, the reason shall be stated on the application. . . . Whenever possible these applications shall be reviewed and those persons contacted to fill job openings.

Owner Referral

The Contractor shall notify the Owner if he is unable to maintain the indicated level of minority workers on the project. The Owner may then refer qualified minority workers to the project for employment and the contractor shall so employ this person or persons.

The contractor's promises to utilize specified minority recruitment organizations, to accept qualified minority group workers applying for work directly at the job site, and, if unable to maintain the level of minority group employment specified in the manning tables, to accept qualified minority group workers referred by the university, assure Harvard that the contractor will retain a receptive attitude towards minority group hiring. The contract fails, however, to relate the specified hiring practices to the contractor's arrangements with union local hiring halls. Read literally, the contractual language might force the contractor to choose between breaking either his contract with the university or a preferential hiring hall agreement. ${ }^{269}$

Several other problems also remain unresolved. First, intransigent union locals could undercut the entire manning tables program. Second, even if the union locals allowed the contractor to bypass the hiring

268 Exec. Order No. 11,246 $\$ 202(7), 3$ C.F.R. 403 (1970), 42 U.S.C. $\$ 2000 \mathrm{e}$ (Supp. V, 1970).

269 For a discussion of hiring hall arrangements, see text accompanying notes 28-36 supra. 
hall to recruit minority group workers, the likely achievement of only temporary work permit status by those workers significantly lessens the long-range benefits of the program. Unless minority workers become union members, they remain dependent on subsequent university construction projects or on a continued union policy of granting them temporary work permits. ${ }^{270}$

The Harvard contract thus leaves significant gaps respecting minority group hiring which Harvard cannot remedy by merely altering the contractual language. The contractor's arrangement with the union local hiring halls is solidified before the university negotiates the construction contract. And because the construction industry does not require the unions to bargain with the builder, the university does not deal directly with the unions, and thus cannot reach the institutions wielding the bulk of the power to increase minority group employment. ${ }^{271}$

\section{Training Program}

The Contractor and his subcontractors shall actively seek to initiate and shall participate in industry training programs for minority workers.

Should an industry-wide training program be instituted which, in the judgment of the Owner and the Contractor, meets the terms and conditions of [the equal employment opportunity provisions], the provisions of such program shall be the basis for evaluating compliance ....

The Contractor and his subcontractors shall support the apprenticeship programs and shall actively seek out and sponsor minority applicants for admission to such programs. The Owner may refer such persons to the Contractor. ${ }^{272}$

The training program provisions are of necessity vague. Their primary purpose is to assure the university of contractor support for any industrywide training program established in the area after the conclusion of the contract.

The contractor's participation in an acceptable industrywide training program provides a basis for evaluating compliance with his entire obligation under the equal employment opportunity clause. Similar provisions are found in the Philadelphia Plan, ${ }^{273}$ and the Department

270 Of course, unions cannot legally deny membership on the grounds of race. Civil Rights Act of 1964 \$703(c), 42 U.S.C. \$2000e-2(c) (1964). As discussed above, union membership has become essential to steady employment in the building trades. Text accompanying notes 28-36 supra.

271 See text accompanying notes 15-70 supra.

272 The provisions discussed are those negotiated in the second Harvard contractfor the construction of public health facilities. The purpose of the primarily linguistic changes in the original language was to dispel any suggestion that the contractor was unilaterally obligated to initiate a training program on the construction site.

273 Note 222 supra. 
of Labor has exempted participants in such programs in Chicago and Pittsburgh from any other duty of affirmative action. ${ }^{274}$

These provisions in the Harvard contract and the OFCC rulings put the whole "minority employment target" approach in different perspective. Manning tables were adopted to prevent discrimination against qualified minority group workers by providing specific standards for contractor compliance. The willingness of both the Government and Harvard to forego the target approach if the contractor participates in a suitable training program shows that, in their opinion, the main problem in the construction industry is not overt discrimination against qualified minority group workers but the absence of such workers. And even though the Government and the university might prefer to have both manning tables and a training program, their bargaining priorities are clear.

\section{Conclusion}

The university attempting to promote minority group employment in the construction industry has a number of alternative courses of action open, but each of them raises serious difficulties.

\section{A. A University Acting Alone}

\section{Postcontract Stage}

Once the contract is operative and the contractor's affirmative action plan has been approved by the administering agency, the university is unlikely to be able to secure a significant increase in the number of minority group workers on the job merely by trying to enforce the contract.

Because the grantee of federal funds cannot bring an administrative complaint through the formal procedures established by the Executive Order, ${ }^{275}$ it must rely on informal means to activate the administrative process. The Tufts experience amply demonstrates that administrative action is unlikely to proceed very rapidly, and will ordinarily involve only investigation and conciliation. Meanwhile the construction may be completed, mooting the central issue. Federal compliance standards are so vague that the university may not be able to risk the liability for damages to the contractor for unilaterally suspending the contract in the hope that the administering agency will take action. The judicial system hardly offers better prospects for relief. $^{276}$ Possibly, the agencies or courts will give more meaning to

274 See 1 CCH EMP. Prac. GuIde ๆf 5013-15; note 219 supra.

275 See text accompanying notes $133-52$ supra.

276 See text accompanying notes 165-214 supra. 
the concept of affirmative action, whether on a case-by-case basis, or by broad regulation. The Allen-Bradley case ${ }^{277}$ shows an administrative willingness to look behind a paper program to the actual effects of employer practices on the minority groups; that case, moreover, parallels judicial treatment of employment practices under title VII of the Civil Rights Act of 1964.278 Nevertheless, administrative preemption may prevent, and primary jurisdiction may delay too long, effective judicial relief.

\section{Precontract Stage}

The university can more effectively ensure compliance with a program of equal employment opportunity by inserting concrete standards for affirmative action in its contract. The Harvard contract shows, for example, that a university can incorporate targets for minority employment into the construction contract to judge the effectiveness of the contractor's affirmative action. The Harvard model can be improved, however, by the articulation of more specific criteria for measuring the contractor's good faith if the targets are not met. A major problem with the target approach is the absence of reliable statistics for evaluating the reasonableness of the targets. The university, moreover, cannot reach the contractor's preexisting hiring agreements and collective bargaining arrangements with the unions. The contractor may be unable to carry out fully the hiring provisions of the contract, and the minority group workers he hires may be unable to secure further employment after the job is completed.

The establishment of numerical targets is an effective means for solving only the problem of discrimination against qualified minority group workers. The pool of skilled minority workers in the labor force is disproportionately small. The pool has been kept small by longstanding patterns of discrimination in training and entry into the construction trades. On-the-job training programs designed to alter those patterns of discrimination and elimination of unnecessarily onerous union membership requirements would be attractive elements for inclusion in the university's contract. Training programs require continuous employment over a long period to be successful, and a single university, except the rare one creating an entire new campus, is unlikely to be able to provide that employment. Even then, relatively few workers could be trained to full journeyman status through a single private training program. The absence of a direct bargaining

277 [Aug. 1968-April 1969 Transfer Binder] CCH LAB. L. REP. $\int 8065$ (OFCC Dec. 17, 1968), aff'd, [Aug. 1968-April 1969 Transfer Binder] CCH LAB. L. ReP. If 8070 (Sec'y of Labor Jan. 16, 1969).

278 Text accompanying notes 107-30 supra. 
relationship with the unions and the lack of significant leverage, moreover, makes university alteration of membership requirements quixotic.

\section{B. Concerted University Action}

\section{Postcontract Stage}

Concerted action can add only the increased political and moral pressure that comes from additional numbers to the efforts of the individual university. The universities could make common cause with other recipients of federal construction grants, such as hospitals, Model Cities programs, and other institutions under public pressure to promote nondiscriminatory employment. But the risk of disparate interests increases with the variety of the institutions and their objectives.

\section{Precontract Stage}

In the precontract stage, the development of a standard compliance clause by a consortium of grantees could strengthen the bargaining position of each of the members. Agreement on a well-considered set of contract terms would provide insulation from pressures of both students and contractors. The group of six universities collaborating after the Tufts crisis found it difficult, however, to reach an agreement on a compliance clause. Those schools not experiencing severe student disruptions were unwilling to agree to provisions that would substantially increase their building costs. ${ }^{279}$

Similarly, a consortium of universities might be able to pool their resources to produce an adequate labor market study, but governmentfinanced studies still seem preferable because of their official character.

Concerted university action is potentially most effective in the area of training. ${ }^{280}$ First, concerted action might persuade the unions to become involved in such a program. Union participation is essential to a training program to ensure the trained minority worker employment security through union membership. Second, concerted action

279 Students were well aware of this response, and their strategy was to put pressure on one university after another. Unions and contractors also tried to isolate the universities and fragment joint efforts. In March 1970, in a union-contractor effort to draft a regional training program for Boston, a clause was included to bar any contractor from participating in the program who had signed a contract involving numerical goals or manning tables. Telephone interview with Paul Parks, Boston Model Cities Administrator, Mar. 27, 1970.

280 Apart from increasing minority group representation in the labor force, universities might also aid black contractors. Presently few black contractors are working on large-scale construction projects because of inexperience and inability to secure bonding required by federal bidding regulations. Universities acting together should provide work opportunities and perhaps even bond black contractors for university construction. 
distinctly enhances the prospects for the continuity of training necessary for a viable program, especially if various other institutions can be induced to participate.

Some models are already available for such a program. Recently, contractor, union, and minority group representatives executed a "Boston Area Construction Industry Equal Employment Opportunity Agreement" providing for recruitment, training, and employment of minority group workers on construction projects in the Boston metropolitan area. The agreement contemplates the recruitment of trained journeymen workers from the Boston area and the attainment of union membership status. In addition, the agreement provides for recruitment and on-the-job training for untrained and partially trained workers. Those minority group members seeking to enter regular apprenticeship programs are classified as preapprentices and accorded supplementary training. Assignment and experience evaluation of other minority group workers is made by operations committees for each trade composed of representatives of each of the signatory organizations. Partially trained workers, designated advanced trainees, are accorded job preference and paid at an apprenticeship wage commensurate with their performance. Untrained workers, designated trainees, are paid starting apprenticeship wages. ${ }^{281}$

Nevertheless, university action in the training area remains speculative. Lacking a direct legal relationship to the unions, even a consortium of universities may not have sufficient leverage within the total construction taking place in the area to accomplish its objective of establishing a training program. Certainly the universities would be unable to mitigate overly restrictive union membership requirements so that minority group members successfully completing the training program would be automatically admitted to the union. Even the Boston Plan fails to curtail effectively union control over its membership policies-the agreement simply calls for vigorous efforts to secure union status for minority group workers.

\section{Government Action}

Executive Order 11246 imposes an obligation on the grantee of federal construction funds "to assist and cooperate actively" with

281 In recent months, similar plans have either been executed or negotiated in several major cities, including Los Angeles, Chicago, St. Louis, New York, and Pittsburgh. The Department of Labor, which has been responsible for a great deal of this private activity because of its threat of a government-imposed Philadelphia Plan, has issued a "Model Area Wide Multi-Employer" agreement with many of the same provisions found in the Boston Plan. Program to Achieve Equal Job Opportunity in Federally-Funded Construction Work in 19 Cities, 1 CCH EMP. PRAC. GUIDE โ5015 (Feb. 9, 1970). For a pessimistic analysis of results under these plans in several cities, see TIME, Aug. 17, 1970, at 61. 
federal authorities in implementing the Order's equal employment opportunity objectives. A realistic appraisal of the limitations on official enforcement capability shows the necessity for grantee cooperation. Even with greatly increased manpower and money, the federal enforcement agencies could not, as a practical matter, provide the detailed monitoring and continuous pressure at each construction site necessary to guarantee equal employment opportunity. The imposition of the duty on the grantee represents a delegation of enforcement responsibility to those in the best position to find out about the contractor's employment policy. The Order does not, however, fully mobilize the grantees' potential for enforcement. The Secretary of Labor and the agencies should take several steps to utilize this potential fully.

First, the Order should be clarified to ensure grantees access to judicial and administrative remedies. The regulations should provide standing for grantee complaints to initiate formal administrative enforcement procedures. Moreover, the regulations should be redrafted to eliminate the possibility of administrative preemption and thereby enable judicial consideration of grantee complaints. Provision for notice to the enforcement agencies, if the parties had failed to join them, would enable the Government to interpose its views on the merits of the controversy and appropriate relief, minimizing the possibility of conflicts between administrative and judicial dispositions.

Even more significant, the administrative agencies could improve the contractual bargaining position of the grantees by providing areawide percentage targets on the pattern of the Philadelphia Plan that grantees would be required to incorporate into their contracts. Required targets would insulate the grantee from contractor pressure and facilitate self-regulation by the parties, without the necessity of administrative or judicial intervention. Such targets are within the rulemaking authority of the Secretary of Labor under the Order.

At a minimum, the Government should be able to provide reliable official labor market statistics, on the basis of which universities could bargain for specific targets in their contracts. Reliable statistics for the Boston-Cambridge area, for example, would help cure the weaknesses of the Harvard contract.

In the end, however, targets may only expose the relatively small size of the pool of qualified minority group workers. One of the most important Government objectives therefore should be the creation of training programs to increase this minority pool. First, the Government should continue to help fund apprentice "outreach" programs designed to seek out minority youth and provide specialized training, coaching, and orientation for entrance into regular union apprenticeship 
programs. ${ }^{282}$ Second, the Government should encourage the development of industrywide training programs designed for minority group workers unable to utilize regular apprenticeship routes. This encouragement can take the form of substantive regulations ${ }^{283}$ or financial support ${ }^{284}$ or both. Grantees could then tie their contracts to effective programs which they could not have created on their own.

Finally, the Government should proceed directly against the unions both under title VII and perhaps by alteration of the Executive Order. Private efforts to modify restrictive policies have been unsuccessful; Government action should be increased to eradicate membership standards which adversely affect minority group workers unnecessarily.

282 BoK \& DunLoP, supra note 9, at 131-32.

283 See N.Y. Times, Apr. 12, 1970, $\$ 1$, at 28, col. 4 (requirement of one trainee for every four journeymen on New York City-financed construction); 1 CCH EMP. PrAC. GUIDE $\{5015$ (model areawide training program agreement).

284 See Manpower Development \& Training Program, 42 U.S.C. \$\$2571-620 (Supp. V, 1970). 